University of Pennsylvania Carey Law School

Penn Law: Legal Scholarship Repository

Faculty Scholarship at Penn Law

8-8-2015

\title{
The Importance of Being Dismissive: The Efficiency Role of Pleading Stage Evaluation of Shareholder Litigation
}

Lawrence A. Hamermesh

Widener Law

Michael L. Wachter

University of Pennsylvania Carey Law School

Follow this and additional works at: https://scholarship.law.upenn.edu/faculty_scholarship

Part of the Business Law, Public Responsibility, and Ethics Commons, Business Organizations Law Commons, Civil Procedure Commons, Corporate Finance Commons, Evidence Commons, Law and Economics Commons, Litigation Commons, and the Policy Design, Analysis, and Evaluation Commons

\section{Repository Citation}

Hamermesh, Lawrence A. and Wachter, Michael L., "The Importance of Being Dismissive: The Efficiency Role of Pleading Stage Evaluation of Shareholder Litigation" (2015). Faculty Scholarship at Penn Law. 1588.

https://scholarship.law.upenn.edu/faculty_scholarship/1588

This Article is brought to you for free and open access by Penn Law: Legal Scholarship Repository. It has been accepted for inclusion in Faculty Scholarship at Penn Law by an authorized administrator of Penn Law: Legal Scholarship Repository. For more information, please contact PennlawIR@law.upenn.edu. 
Working Paper - draft of 8-19-15

\title{
The Importance of Being Dismissive: The Efficiency Role of Pleading Stage Evaluation of Shareholder Litigation
}

\author{
Lawrence A. Hamermesh ${ }^{1}$ \& Michael L. Wachter ${ }^{2}$
}

\begin{abstract}
It has been claimed that the risk/reward dynamics of shareholder litigation have encouraged quick settlements with substantial attorneys' fee awards but no payment to shareholders, regardless of the merits of the case. Fee-shifting charter and bylaw provisions may be too blunt a tool to control agency costs associated with excessive shareholder litigation, and are in any event now prohibited by Delaware statute. We claim, however, that active judicial supervision of public company shareholder litigation at an early stage reduces the costs of frivolous litigation to shareholders by separating meritorious from unmeritorious litigation before the full costs of discovery are incurred. Using procedures and doctrines that have not previously been catalogued and appreciated as a coherent set of interrelated dynamics, the Delaware Court of Chancery has relied on the motion to dismiss as the primary procedural vehicle for accomplishing that early stage triage. Such early stage analysis depends upon consideration of essentially undisputed facts, and upon the availability of such facts to the plaintiff shareholder through sources that compensate for the problem of asymmetric access to relevant information. The motion to dismiss in representative shareholder litigation has thus come to resemble, and substitute for, the motion for summary judgment. The Delaware courts' atypical demand for, and unusual willingness to consider, extensive facts in resolving motions to dismiss encourage defendants to supply relevant information voluntarily, on a cost efficient basis that avoids largely unlimited discovery. Where time constraints preclude disposition via a motion to dismiss, the motion for expedited discovery must necessarily come to serve the same efficiency promoting functions as the motion to dismiss, and the Court of Chancery has come to apply essentially the same level of substantive factual review of the merits encountered in resolving motions to dismiss. The result is a system in which cases are dismissed or settle at the motion to dismiss stage: from 2011 through 2014, for example, there were only four public company shareholder

${ }^{1}$ Ruby R. Vale Professor of Corporate and Business Law, Widener University Delaware Law School; Director, Widener Institute of Delaware Corporate and Business Law. Professor Hamermesh is a member of the Council of the Delaware State Bar Association ("DSBA") Corporation Law Section, which developed and advocated the adoption of recent Delaware legislation discussed in this Article. The views expressed here, however, are solely those of the authors, and do not necessarily represent the views of the DSBA or any of its institutional components or representatives.

${ }^{2}$ William B. Johnson Professor of Law and Economics, University of Pennsylvania Law School; Co-Director, Institute for Law and Economics at the University of Pennsylvania. The authors gratefully acknowledge the contributions of Gregory Williams, William Lafferty, Gregory Varallo, Donald F. Wolfe, Jr., Martin Lessner, [etc], and the research assistance of Nickolas Bogdanovich, Michael Arsiotis, Sabrina Hendershot, Jessica Paletsky, and Tyler Cook.
\end{abstract}


class or derivative suits in which the Court of Chancery resolved the case after trial. With the likely concentration of deal litigation in the Delaware courts resulting from increasingly prevalent exclusive forum charter and bylaw provisions, the motion to dismiss and the motion to expedite discovery are likely to become even more important in promoting the efficient conduct of shareholder class and derivative litigation involving public companies.

\section{Contents}

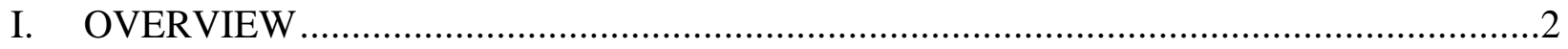

A. A Public Solution to the Problem of Unmeritorious Shareholder Litigation .....................2

B. Notice Pleading, Fact Pleading, and Early Stage Triage ............................................6

C. The Efficiency Role of Pleading Stage Evaluation .................................................10

D. Mapping the Territory: Derivative Suits and Deal Cases ..........................................15

II. THE PROCEDURAL FOUNDATIONS OF PLEADING STAGE EVALUATION...........18

A. Information Gap-Reducing Measures ..................................................................18

1. Mechanisms of Pleading Stage Access to Information..........................................19

2. Requiring Particularized Pleading ...............................................................24

3. Considering Facts Not Specifically Pleaded in the Complaint.................................25

B. Measures to Improve the Predictive Value of Pleading Stage Evaluation .......................31

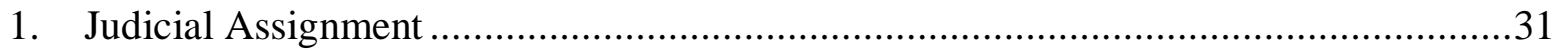

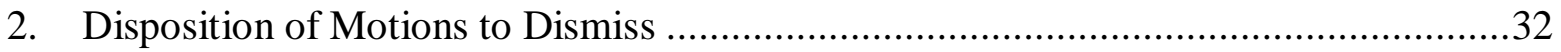

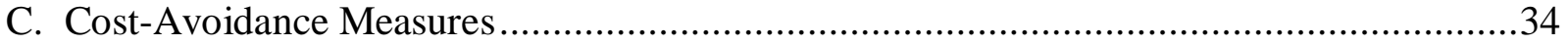

III. PLEADING-STAGE EVALUATION OF REPRESENTATIVE SHAREHOLDER

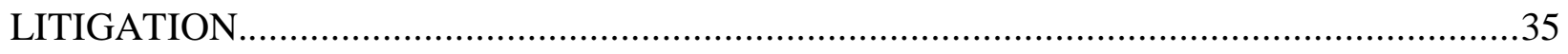

A. Aronson: Building the Triage System for Derivative Litigation..................................36

B. Extending the Fact Pleading Approach to Other Cases …........................................38

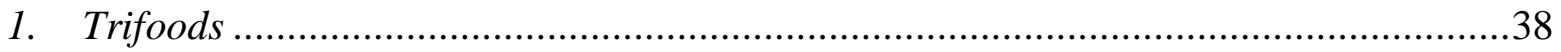

2. Caremark and Stone v. Ritter: Fact Pleading in Oversight Cases ............................42

3. Krim: Fact Pleading Emerges in Deal Cases ...................................................45

4. Dismissing Non-Revlon Revlon Cases................................................................48

5. Dismissing Deal Cases Involving Controlling Stockholders ..................................52

i. Claims Against Disinterested Directors......................................................53

ii. Sales by a Controller to a Third Party .......................................................55 
iii. Controller Freeze-Outs Conditioned on Special Committee and Minority Stockholder

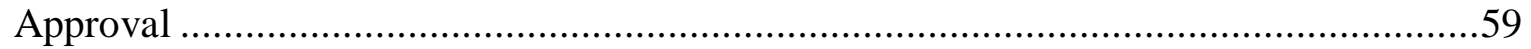

C. The Evolution and Importance of the Motion to Expedite Discovery ............................62

D. Cases Denying Motions to Dismiss, and the Promotion of Efficient Settlements............66

E. Limits of Pleading Stage Evaluation of Shareholder Litigation ..................................72

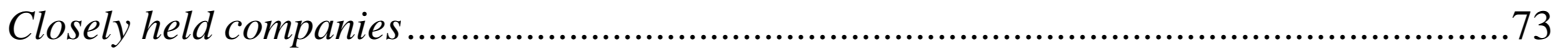

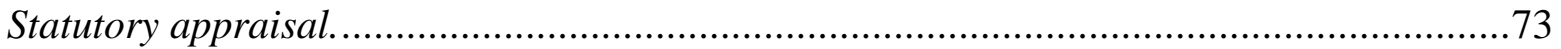

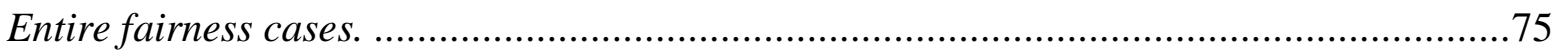

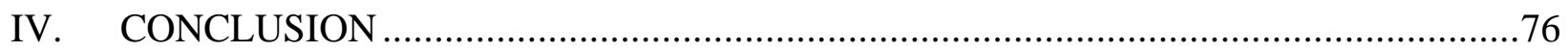

\section{OVERVIEW}

\section{A. A Public Solution to the Problem of Unmeritorious Shareholder Litigation}

The torrid pace of recent merger and acquisition activity has heartened - and enriched the lawyers, bankers, and financial advisers who negotiate, craft, and finance those transactions. ${ }^{3}$ At the same time, however, many observers have noted and criticized the fact that litigation by shareholders challenging those transactions has become ubiquitous: almost every deal valued at over $\$ 100$ million is subjected to litigation. ${ }^{4}$ Given the size of the financial stakes involved, and

${ }^{3}$ See, e.g., Dana Mattioli and Dana Cimilluca, Fear of Losing Out Drives Deal Boom, Wall St. J. (June 26, 2015) (“Companies are merging at a pace unseen in nearly a decade.”); Diego Villegas-Sierra, Global M\&A Revenue at Highest YTD Level Since 2011, May 28, 2015, available at http://www.dealogic.com/media/market-insights/ib-revenue-statshot/; Paul Harman, “Global Acquisition Related Financing Revenue at Highest YTD Level Since 2007," available at http://www.dealogic.com/media/market-insights/ib-revenue-statshot/; Jesse Solomon, Boom

Time for Mergers and Acquisitions, Jun. 16, 2014, available at http://money.cnn.com/2014/06/16/investing/mergers-and-acquisitons-boom/index.html (reporting " $\$ 786$ billion worth of mergers and acquisitions in the United States" in just the first half of 2014, substantially higher than any year since 2007).

${ }^{4}$ Robert M. Daines \& Olga Koumrian, Shareholder Litigation Involving Mergers and Acquisitions, CORNERSTONE RES. (Feb. 2013), https://www.cornerstone.com/GetAttachment/9d8fd78f-7807-485a-a8fc-4ec4182dedd6/2012Shareholder-Litigation-Involving-M-and-A.pdf (stating that in 2012, shareholders challenged 93 percent of merger and acquisition deals valued over $\$ 100$ million and 96 percent of transactions valued over \$500 million.); Matthew D. Cain \& Steven M. Davidoff Solomon, A Great Game: 
the prospect that even modestly successful litigation in that arena can yield substantial fee awards for the plaintiffs' counsel who initiate it, ${ }^{5}$ the frequency of such litigation is not surprising. The rampant phenomenon of early settlements of such litigation, however, usually for modified disclosure only, ${ }^{6}$ with no improvement in the deal price, has led some to claim that Delaware "hasn’t done enough to curb” a "growing tide of shareholder litigation," 7 and that such litigation amounts to a wasteful "merger tax" ultimately borne by shareholders and collected by the plaintiffs' class action bar. ${ }^{8}$

A tax on mergers, however, is not a deadweight loss to the system if the litigation that it funds encourages managerial conduct that enhances shareholder value. But that enhancement

The Dynamics of State Competition and Litigation, 100 IOWA L. REV. 465, 475 tbl. I (2015) (stating that in 2011, 92.1 percent of public company merger and acquisition deals were challenged whereas in 2007, 38.7 percent of deals were challenged, this occurred even as the number of total deals sharply declined from 248 deals in 2007 to 127 deals in 2011). The number of suits brought per deal is also on the rise. In 2007, the mean number of independently filed suits brought per deal was 3.1. Id. In 2011, this incidence had risen to 5 suits per deal. Id. at 476 tbl. II. See also Daines supra (finding that among deals valued over \$100 million, an average of 4.8 lawsuits filed per deal; for deals valued over \$500 million, an average of 5.4 lawsuits filed per deal). Another recent trend has been a sharp increase in the incidence of appraisal petitions. See generally Charles R. Korsmo and Minor Myers, Appraisal Arbitrage and the Future of Public Company M\&A, 92 WASH. U. L. REV. [ ] (2015). Approximately five percent of appraisal-eligible transactions led to some form of appraisal litigation from 2004 through 2010. Id. By 2013, more than fifteen percent of appraisal-eligible transactions attracted an appraisal petition. $I d$.

${ }^{5}$ Cain \& Davidoff Solomon, note [4] above, 100 IOWA L. REV. at 481-482, tbls. IVA and IVB.

${ }^{6}$ Id. at 478 tbl. III.

${ }^{7}$ Liz Hoffman, Dole and Other Companies Sour on Delaware as Corporate Haven, Aug. 2, 2015, available at http://finance.yahoo.com/news/dole-other-companies-sour-delaware023800338.html.

${ }^{8}$ U.S. Chamber Institute for Legal Reform, by Andrew Pincus, The Trial Lawyers' New Merger Tax: Corporate Mergers and the Mega Million-Dollar Litigation Toll on Our Economy, Oct. 24, 2012, available at http://www.instituteforlegalreform.com/resource/the-trial-lawyers-newmerger-tax-corporate-mergers-and-the-mega-million-dollar-litigation-toll-on-our-economy/ (describing merger litigation as "extortion through litigation, plain and simple" (emphasis in original)). 
could be more than offset if corporate defendants (and, indirectly, their shareholders) were required to bear the substantial costs of discovery and trial (or pay substantial plaintiff's attorneys fees in settlements to avoid such costs) in cases with little or no merit. And given the high percentages of deal transactions that lead to complaints, it would be difficult to conclude that all deal litigation has substantial merit. That problem, in turn, presents the central conundrum addressed in this Article: how can the corporate litigation system separate meritorious shareholder derivative and deal claims from those that lack merit, and do so early enough in the proceedings to avoid the costs of discovery and trial?

One possible approach surfaced prominently after the Delaware Supreme Court’s 2014 opinion in ATP Tour Inc. v. Deutscher Tennis Bund, ${ }^{9}$ some corporations and their advisers engaged in a brief dalliance with bylaws that purported to shift the costs of defending shareholder litigation to plaintiff shareholders whose lawsuits were anything other than totally successful. ${ }^{10}$ At least in Delaware, that dalliance was thwarted before it became a commonly

${ }^{9} 91$ A.3d 554 (Del. 2014).

${ }^{10}$ E.g., Wilson Sonsini Goodrich \& Rosati LLP, Delaware Supreme Court Endorses "FeeShifting" Bylaw in Certified Question of Law, (May 12, 2014), available at https:/www.wsgr.com/WSGR/Display.aspx?SectionName=publications/PDFSearch/wsgralertfee-shifting.htm ("The practical effect of [the ATP] decision ... is that many boards of directors of private and public Delaware corporations should seriously consider adopting fee-shifting bylaws of their own”); Claudia H. Allen, Fee-Shifting Bylaws: Where Are We Now?, (Feb. 2, 2015), available at http://www.bna.com/feeshifting-bylaws-n17179922685/ (noting that between May 2014 and February 2015, thirty-nine public companies, thirty incorporated in Delaware, adopted fee-shifting charter or bylaw provisions); see also Letter from Lisa Rickard, President of U.S. Chamber Institute for Legal Reform, to Norman Monhait, Chairman of Section of Corp. Law Del. State Bar Ass'n Letter to the Delaware State Bar Association in Response to the Corporation Law Council's March 6 Proposal (Apr. 8, 2015) available at http://www.instituteforlegalreform.com/uploads/sites/1/de-bar-letter-4_8_2015.pdf ("What is needed are solutions - either in terms of bylaw authorization or additional tools for the Court of Chancery - that eliminate the incentive to file meritless lawsuits in the first place ... . Limiting corporations' authority to adopt fee-shifting bylaws, and thereby depriving them of the ability to protect shareholders against the cost of these claims, ... is unjustified and unwise ... ."). 
adopted practice: the use of such bylaws has now been prohibited by legislation. ${ }^{11}$ The Delaware State Bar Association committee that drafted that legislation nevertheless recognized that it was important to identify ways "to address and deter litigation of limited merit." ${ }^{12}$ Instead of private ordering, however, that committee advocated a solution based on public ordering: specifically, it urged that "courts can and should be trusted to address real problems effectively when and if they arise on a case by case basis."13 That public ordering solution is the focus of this Article. To assure, or at least make it more likely, that only meritorious cases reach the stage of full discovery and trial, the Delaware courts have developed an intricate but highly efficient system for managing the flow of shareholder complaints.

This Article presents for the first time an inventory and analysis of the interrelated procedures and doctrines that constitute this system. Most fundamentally, this system resolves shareholder litigation by encouraging the early presentation of relevant facts pleaded in the complaint, and by either dismissing the complaint if those facts fail to demonstrate legal merit, ${ }^{14}$ or identifying how the complaint is meritorious, in a fashion that encourages the protagonists to settle. With its emphasis on early, and often extensive, factual inquiry, the motion to dismiss in

${ }^{11}$ SB No. 75, $148^{\text {th }}$ Gen. Assemb. (Del. 2015), amending tit. 8, DEL. CoDE ANN., $\S \S 102$ and 109(b), available at http://legis.delaware.gov/LIS/lis148.nsf/vwLegislation/SB+75/\$file/legis.html?open (providing that the certificate of incorporation and the bylaws "may not contain any provision that would impose liability on a stockholder for the attorneys' fees or expenses of the corporation or any other party in connection with an internal corporate claim ....”)

12 Delaware State Bar Association Corporation Law Section Council, Explanation of Council Legislative Proposal, at 7, available at http:/www.corporatedefensedisputes.com/files/2015/03/COUNCIL-SECOND-PROPOSALEXPLANATORY-PAPER-3-6-15-U0124513.pdf.

${ }^{13} \mathrm{Id}$. at 8.

${ }^{14}$ For the proponents of the legislation precluding fee-shifting by charter or bylaw provisions, the first item on their list of judicial tools to limit unmeritorious shareholder litigation were "[m]otions to dismiss, which enable the court to terminate litigation at the outset, before expensive discovery proceedings, where the complaint lacks merit on its face.” Id. 
Delaware representative shareholder litigation -- specifically, derivative litigation and class actions asserting breaches of fiduciary duty by the corporation's directors - functions in a fashion similar to the motion summary judgment, but with substantially less pre-motion discovery and its associated costs.

\section{B. Notice Pleading, Fact Pleading, and Early Stage Triage}

Those familiar with principles of civil procedure would not ordinarily expect the motion to dismiss to be such an important tool for early stage triage: ${ }^{15}$ to survive a motion to dismiss, a complaint is only required to set forth "a short and plain statement of the claim showing that the pleader is entitled to relief.” ${ }^{16}$ As first year law students have been taught for decades, this embrace of "notice pleading” is intended to promote the resolution of disputes based on facts presented in evidence at trial, rather than based on the content of pleadings. ${ }^{17}$ And in litigation in which both sides generally bear the costs of litigation equally and the burdens of gathering

${ }^{15}$ See, e.g., William M. Lafferty \& W. Leighton Lord, III, Toward a Relaxed Summary Judgment Standard for the Delaware Court of Chancery: A New Weapon Against "Strike” Suits, 15 Del. J. Corp. L. 921, 927 (1990) ("a motion to dismiss is usually easily defeated by the plaintiff, because of the minimal requirements for a complaint to state a claim under the 'notice pleading' standard in the Delaware Chancery Court Rules.”).

${ }^{16}$ Court of Chancery Rule 8(a) (requiring that a pleading contain only "a short and plain statement of the claim showing that the pleader is entitled to relief.”). The Delaware Supreme Court has explained, moreover, that " $[\mathrm{t}]$ he pleading standards governing the motion to dismiss stage of a proceeding in Delaware ... are minimal.” Cent. Mortg. Co. v. Morgan Stanley Mortg. Capital Holdings LLC, 27 A.3d 531, 536 (Del. 2011). See also A. Benjamin Spencer, Plausibility Pleading, 49 B.C. L. REV. 431, 484-485 (2008) ("Before the shift to 'notice pleading' accomplished by the Federal Rules, motions to dismiss a complaint or to strike a defense were the principal tools by which factually insufficient claims or defenses could be isolated and prevented from going to trial with the attendant unwarranted consumption of public and private resources. But with the advent of 'notice pleading,' the motion to dismiss seldom fulfills this function any more”).

${ }^{17}$ See Conley v. Gibson, 355 U.S. 41, 48 (1957) (“[T] he purpose of pleading is to facilitate a proper decision on the merits.”); see also Richard L. Marcus, The Revival of Fact Pleading Under the Federal Rules of Civil Procedure, 86 CoLuM. L. REV. 433, 454 (1986) ("the problem with common law pleading practice was that, while it led to actual decisions, it often did not lead to merits decisions because cases were frequently resolved on technicalities.”). 
evidence fall upon them more or less equally, the "notice pleading” concept makes sense as a means to avoid unnecessarily costly attention to the formulation of pleadings, when the resolution of the dispute ought to turn instead on an evaluation of actual facts. ${ }^{18}$

In representative stockholder litigation, however, the burdens of discovery fall almost exclusively on the defendants. Thus, one cannot count on symmetry of litigation costs to generate an efficient equilibrium in which unmeritorious cases are either dismissed or not brought at all: the one-sided threat of unchecked discovery costs ${ }^{19}$ becomes a source of leverage for extracting settlement payments without regard to the merits of the litigation. ${ }^{20}$ In that setting, efficiency depends upon a system of judicial supervision and triage at an early stage of the litigation, so that cases lacking merit are dismissed and thereby deprived of their extortive effect, and meritorious cases are identified as such early on and settled, so that the enormous costs of discovery and trial can be avoided.

${ }^{18}$ Paul Stancil, Balancing the Pleading Equation, 61 BAYLOR L. REV. 90, 146 (2009) (“To the extent there exist some cases or claim types for which pretrial costs are typically balanced or favor the defendant, the model demonstrates that the pleading standard should err on the side of correcting informational asymmetries. For those claim types, the risk of strike suit is minimal, and thus the pleading standard can and should legitimately focus upon correcting plaintiff's presumed knowledge deficit. Notice pleading often works.”).

19 The costs of discovery can be significant. See e.g., Judicial Conference Adopts Rules Changes, Confronts Projected Budget Shortfalls, Third Branch (Admin. Office U.S. Cts., D.C.), Oct. 1999, at 2-3 ("Discovery represents 50 percent of the litigation costs in the average case and up to 90 percent of the litigation costs in cases in which it is actively used.”), available at http://www.uscourts.gov/News/TheThirdBranch/99-10-01/Judicial_Conference_Adopts_Rules_ Changes_Confronts_Projected_Budget_Shortfalls.aspx; Frank H. Easterbrook, Discovery as Abuse, 69 B. U. L. REV. 635, 636 (1989) (noting how the high costs of discovery shape litigants' decisions). The costs and abuses of discovery were also a key focus of the debates concerning the Private Securities Litigation Reform Act of 1995 (PSLRA). Pub. L. No. 104-67, 109 Stat. 737 (1995).

${ }^{20}$ Stancil, note [ ] above, at 133 ("When cost disparity significantly favors the plaintiff, the expected trial value of her claim becomes irrelevant to her filing decision. In the extreme, the economic model predicts that a plaintiff may file suit - and the defendant may settle the claim even when the plaintiff's claim is wholly frivolous.”). 
This Article describes the unique and highly evolved system employed in the Delaware courts to achieve that efficiency. For good reasons, that system is notably different from the “notice pleading” system extolled in civil procedure courses: as we demonstrate below, Delaware's system affirmatively encourages reliance on factually specific pleadings as a basis for substantive evaluation of shareholder litigation at an early stage of the proceedings. On the other hand, the Delaware system provides or depends on mechanisms that enable and encourage the plaintiff and the defendants as well to supply relevant information that meaningfully assists the courts in improving the fairness and utility of that substantive, pleading stage evaluation.

As we explain more fully below, the role served by the motion to dismiss in Delaware representative shareholder litigation has come to more closely resemble the role of the motion for summary judgment: it has evolved into a procedure in which, despite occurring at the pleading stage and before formal discovery, the court often evaluates the merits with the benefit of a substantial record, assembled from publicly available information or provided by defendants, consisting of facts essentially beyond dispute. In essence, with the benefit of significant factual inquiry, the motion to dismiss has evolved in Delaware shareholder litigation practice to constitute something of a proxy for a trial: a relatively inexpensive inquiry that approximates the result of a trial, and either avoids further litigation and its attendant costs altogether, or provides the parties with an informed prediction of the result at trial that facilitates rational settlement at an early stage, again, before the bulk of litigation costs is incurred.

Also, as we explain more fully below, ${ }^{21}$ where time pressures in shareholder litigation make the motion to dismiss unavailable as a practical matter - typically, where a shareholder plaintiff seeks a preliminary injunction against completion of a merger - the efficiency-

${ }^{21}$ Part III.C below. 
promoting function of the motion to dismiss has been taken over by the motion to expedite discovery. Instead of examining whether a complaint sets forth facts establishing a "reasonably conceivable" basis for relief, ${ }^{22}$ the court on a motion to expedite discovery engages in a similar evaluation to determine whether the plaintiff has presented "colorable" claims on the merits. ${ }^{23}$ Denial of the motion to expedite enables the defendants to pursue a motion to dismiss, and a typically attendant stay of discovery, ${ }^{24}$ without incurring immediate discovery costs; and denial or grant of the motion to expedite informs the parties of the court's preliminary assessment of the merits, and can facilitate prompt settlement. ${ }^{25}$

In both procedural contexts, the assessment of the merits largely focuses on whether the facts reflect conflicts of interest or some other circumstances sufficient to preclude the judicial deference ordinarily required by the business judgment rule. ${ }^{26}$ In the absence of such facts, the

${ }^{22}$ Cent. Mortg. Co., 27 A.3d at 536 (court must deny a motion to dismiss "unless the plaintiff could not recover under any reasonably conceivable set of circumstances susceptible of proof.”).

${ }^{23}$ E.g., County of York Emples. Ret. Plan v. Merrill Lynch \& Co., 2008 Del. Ch. LEXIS 162, *16 (Del. Ch. Oct. 28, 2008) (to be entitled to expedited discovery, "a plaintiff must articulate a sufficiently colorable claim .... .”). See also Part III.C below.

${ }^{24}$ See Part II.C below.

${ }^{25}$ See Part III.D below.

${ }^{26}$ This is so because the business judgment rule is normally applied in the absence of a showing of interestedness or lack of independence of a majority of directors. When the business judgment rule is applied, a case challenging the actions of directors is likely to be dismissed. "[T]he business judgment rule insulates directors when they make what, in hindsight, turn out to be poor business decisions.” Donald F. Parsons and Jason S. Tyler, Docket Dividends: Growth in Shareholder Litigation Leads to Refinements in Chancery Procedures, 70 WASH. \& LEE L. REV. 473, 483 (2013). See also Orman v. Cullman, 794 A.2d 5, 22 (Del. Ch. 2002) ("To successfully rebut the business judgment rule in this manner, thereby leading to the application of the entire fairness standard, a plaintiff must normally plead facts demonstrating 'that a majority of the director defendants have a financial interest in the transaction or were dominated by a materially interested director.'” (quoting Crescent/Mach I P'rs, L.P. v. Turner, 846 A.2d 963, 979 (Del. Ch. 2000))). Aronson v. Lewis, 473 A.2d 805, 812-16 (Del. 1984) sets forth the now-standard definitions for the terms "interested" and "independent." Interestedness means that the directors "appear on both sides of a transaction [or] expect to derive any personal benefit from it in the sense of self-dealing, as opposed to a benefit which devolves upon the corporation or all 
motion to dismiss is granted and the motion to expedite discovery is denied; but if such facts are presented, the parties are told so and can approach settlement with a better assessment of their prospects at trial.

\section{The Efficiency Role of Pleading Stage Evaluation}

In the remainder of this Article, we examine the rationale, evolution, and components of the system that engages in pleading stage triage of Delaware shareholder class and derivative litigation. We begin with another, somewhat deeper look at the efficiency considerations associated with such litigation.

Corporate governance rules and practices prominently include judicial articulation of director and officer fiduciary duties, and enforcement of those duties through private litigation is supported by something of a bounty system for shareholder plaintiff lawyers. ${ }^{27}$ Such shareholder litigation can generate wealth-producing disciplinary effects. ${ }^{28}$ Those effects are only partly expressed through judgments and settlements in such litigation: there are also unquantifiable benefits where corporate managers and transactional lawyers plan, negotiate and structure transactions with an eye to avoiding the cost and uncertainty of litigation, and therefore heed

stockholders generally.” Id. at 812. "Independence means that a director's decision is based on the corporate merits of the subject before the board rather than extraneous considerations or influences.” Id. at 816.

${ }^{27}$ See John C. Coffee, Jr., Understanding the Plaintiff's Attorney: The Implications of Economic Theory for Private Enforcement of Law through Class and Derivative Actions, 86 COLUM. L. REV. 669 (1986).

${ }^{28}$ See, e.g., Randall S. Thomas \& Robert B. Thompson, A Theory of Representative Shareholder Suits and its Application to Multijurisdictional Litigation, 106 NW. U. L. REV. 1753, 1755 (2012) (summarizing the important role of shareholder litigation in controlling opportunistic managerial behavior and reducing managerial agency costs). 
judicial definitions of appropriate managerial conduct, thereby presumably promoting shareholder wealth-maximizing corporate conduct. ${ }^{29}$

On the other hand, shareholder litigation, particularly in the form of class and derivative actions, presents agency cost issues. ${ }^{30}$ Participants in such litigation (plaintiffs' lawyers, defense lawyers, and director defendants) may have incentives to act in concert to initiate and resolve litigation in ways that impair the interests of the investors who do not directly participate in the litigation and are not individually represented in it. ${ }^{31}$ Thus, the job of minimizing unproductive proceedings is a critical element in promoting the efficiency of shareholder litigation, which, unchecked, can create enormous costs - ultimately borne by shareholders - without contributing meaningful systemic or case-specific benefits. ${ }^{32}$

${ }^{29}$ Judicial definitions of appropriate managerial conduct reign supreme in a system where "fiduciary attacks on announced deals are now the primary vehicle through which the Court develops the rules that govern director conduct and that provide transaction planners (and plaintiffs' lawyers) the basis to plan (or attack) the next deal.” William Savitt, The Genius of the Modern Chancery System, 2012 ColuM. BuS. L. REV. 570, 571.

${ }^{30}$ See e.g., Thomas, note [] above, at 1753 (describing how representative shareholder litigation has two important underlying characteristics that have the potential to increase agency costs: (1) the multiple sources of the legal rights being redressed (creating dynamic opportunities for arbitrage) and (2) the ability of multiple shareholders to seek to represent the collective group in such litigation (creating increased risk of litigation agency costs by those representatives and their attorneys)).

31 Thomas, note [ ] above at 1755 (describing "a serious principal-agent problem that gives the plaintiff's attorney, not the client, the real discretion as to whether to commence suit,” and noting that " $\mathrm{t}]$ his is the likely situation in class and derivative actions where the number of clients is large and the individual injuries small.”).

32 See Daines, note [] above (finding that only a small fraction of lawsuits challenging a merger of acquisition resulted in payments to shareholders, the majority settled for additional disclosures or, less frequently, changes in merger terms, such as deal protection provisions). See also Leo E. Strine, Jr., Lawrence A. Hamermesh \& Matthew C. Jennejohn, Putting Stockholders First, Not the First-Filed Complaint, 69 Bus. LAW. 1, 5 (2013) ("Unless a consistent incentive system can be implemented that encourages representative litigation that benefits stockholders, the representative litigation system may on balance hurt investors more than it protects them.”). 
How does the law handle this efficiency issue? As previously noted, it is the motion to dismiss that provides the primary solution. ${ }^{33}$ And in public company shareholder class and derivative litigation, the Delaware courts have managed the efficiency-promoting function of the motion to dismiss and the motion to expedite discovery particularly well. ${ }^{34}$ Such litigation only

\footnotetext{
${ }^{33}$ Less significant in our view, but also relevant to this issue, are other rules and requirements that have been identified as judicial tools to curb rent-seeking behavior by litigation agents. Such tools include requirements of notice and judicial supervision of class certification and settlement, as well as fee-shifting sanctions and control over awards of representative counsel's attorney's fees. Explanation of Council Legislative Proposal, note [ ] above, at 8. Chancery Court Rule 23(e) and 23.1(c) prohibit dismissal of suits without approval of the court and notice to member of the class thereby allowing the court to supervise any side-dealing on the part of other litigation agents. There are indications that the supervision of settlements by the Court of Chancery in shareholder litigation is becoming more robust, and attentive to avoiding the encouragement of unmeritorious deal litigation. Acevedo v. Aeroflex Holding Corp., C.A. No. 7930-VCL (July 8, 2015) (transcript ruling at 66) ("what we thought was a nice way of getting rid of meritless Delaware litigation, in fact, sweeps much more broadly and has overall significant deleterious effects leading to the types of levels of litigation documented by Professor Davidoff and by the Cornerstone Research studies [cited in fn. [ ] above].”).

${ }^{34}$ We do not assert, however, that Delaware is the only jurisdiction that attempts to employ the motion to dismiss to improve the efficiency of representative litigation. Although the motion to dismiss may or may not operate more efficiently in Delaware shareholder litigation than it does under the scheme established under the Private Securities Litigation Reform Act of 1995 (Pub. L. 104-67, 109 Stat. 737), that Act does establish features that resemble the approach taken in Delaware, including heightened pleading standards (15 U.S.C. §21D(b) (requiring that the complaint identify each alleged misstatement and "state with particularity facts giving rise to a strong inference that the defendant acted with the required state of mind”) and largely mandatory stays of discovery pending disposition of the motion to dismiss (15 U.S.C. §21D(3)(B)) (requiring that "all discovery and other proceedings shall be stayed during the pendency of any motion to dismiss," absent a finding of necessity "to preserve evidence or to prevent undue prejudice”).
}

The Canadian framework regulating securities fraud litigation is even more explicit in its focus on the use of a preliminary inquiry into the merits of the litigation as a tool to manage the efficiency of such litigation. See Davies, Ward, Phillips, \& Vineberg, LLP, Secondary Market Liability: Supreme Court of Canada Clarifies the Screening Mechanism for Class Actions (Apr. 21, 2015), available at https://reaction.dwpv.com/rs/vm.ashx?ct=24F76F1AD2E30AEDC1D180A9D12E9010DCBE7B B3D38714DD4CF371647BF8D90DDD78035 (describing the opinion of the Canadian Supreme Court in Theratechnologies inc v. 121851 Canada inc., 2015 SCC 18, applying Article 225.4 of the Québec Securities Act, which requires that the court preliminarily determine whether "there is a reasonable possibility that it will be resolved in favour of the plaintiff," and holding that "the 
very rarely proceeds to trial: from 2011 through 2014, for example, there are only four instances of such litigation in which the Court of Chancery resolved the case after trial. ${ }^{35}$ The Delaware courts have achieved this efficiency for well-documented reasons: the litigation is supervised by a specialized court that hears hundreds of these cases ${ }^{36}$ can understand the setting, evaluate the facts, and thus offer a highly predictive assessment, at the pleading stage, of who would win at trial. The Delaware courts accomplish this procedural streamlining through a variety of means, which combine to make the motion to dismiss and the motion to expedite discovery a meaningful “test run,” even if not a perfect replica, of the trial. This is achieved primarily by reducing the information gap between the two stages: in various ways, Delaware law and practice result in providing a good deal of critical information to the court at the pleading stage, and the court can in turn render an assessment of the case that will better approximate the result that would ensue if a trial were held, but without incurring the costs of that process. In derivative suits, for example, the Delaware courts have actively encouraged shareholder plaintiffs to use the "tools at hand" - i.e., statutory rights to inspect corporate books and records - to provide a fuller factual

gatekeeping role of the courts under article 225.4 requires that the courts 'undertake a reasoned consideration of the evidence to ensure that the action has some merit'.”).

35; In re Rural Metro Corporation Stockholder Litig., C.A. No. 6350-VCL (March 7, 2014); In re Trados Inc. S’holder Litig., C.A. No. 1512-VCL (Aug. 16, 2013); In re S. Peru Copper Corp. S'holder Derivative Litig., C.A. No. 961 (Dec. 20, 2011); S. Muoio \& Co. LLC v. Hallmark Entm't, et al., C.A. No. 4729-CC (March 9, 2011); In re John Q. Hammons Hotels Inc. S'holder Litig., C.A. No. 758-CC (Jan. 14, 2011).

${ }^{36}$ See Parsons, note [] above at 473 ("Delaware's volume of corporate and alternative business entity cases and the responsiveness of its courts, its legislature, and the legal marketplace generally accelerate the development of refined doctrine, measured balance, and valuable predictability. In short, with repeat experience comes ready expertise and real efficiency.”); William H. Rehnquist, The Prominence of the Delaware Court of Chancery in the State-Federal Joint Venture of Providing Justice, 48 Bus. LAw. 351, 354 (Nov. 1992) (praising the Court of Chancery for refining the law so that business planners may order their affairs to avoid lawsuits). 
foundation for the pleading stage evaluation of the derivative case. ${ }^{37}$ In class actions challenging mergers ("deal cases”), the factual foundation for the motion to dismiss (and the motion to expedite discovery) is typically enriched by a proxy statement, a Schedule 14D-9, or even by discovery taken in parallel statutory appraisal litigation. ${ }^{38}$

What we find, in general, is that the Delaware courts dismiss cases or grant expedited discovery, or not, based on whether the pleaded facts create some reasonable doubt that the corporate decision makers (usually the directors) were disinterested and independent and acted in good faith. ${ }^{39}$ More specifically, our essential claim is that the Delaware courts have developed and applied a rubric for evaluation that is similar in multiple procedural contexts: whether examining a complaint for “colorability” for purposes of a motion to expedite discovery, assessing "reasonable conceivability” for purposes of a motion to dismiss a deal case for failure to state a claim, or applying the pre-suit demand requirement of Rule 23.1 in a derivative suit, the courts are essentially engaging in the same evaluation, namely whether the available facts create some reasonable doubt that the corporate decision makers were disinterested and acted in good faith.

After a brief review of the two principal types of representative shareholder litigation, we turn below to identify the categories of procedural rules that enable this triage system to work fairly, and to describe how those rules accomplish that goal. We next trace the remarkable evolution of the use of fact pleading in the triage system, beginning with derivative litigation applying the pre-suit demand requirement of Court of Chancery Rule 23.1, and continuing into other areas of representative shareholder litigation in which more generally applicable rules of

\footnotetext{
${ }^{37}$ See Part II.A.1.

${ }^{38} I d$.

${ }^{39}$ See note [ ] above.
} 
civil procedural control. Next, we examine the increasing importance, but logical development in the context of the Delaware system for controlling excessive litigation, of the motion to expedite discovery as a means of pleading stage triage. Finally, to show how this system works in detail, we examine several cases in which the denial of a motion to dismiss or the ruling on a motion to expedite discovery in representative shareholder litigation aided in the efficient resolution of the case.

\section{Mapping the Territory: Derivative Suits and Deal Cases}

Understanding how the Delaware courts perform the triage function in stockholder litigation requires examination of two critical procedural contexts: the motion to dismiss and, less obviously, the motion to expedite discovery. It is also necessary to appreciate that stockholder litigation under Delaware law comes in two flavors: derivative suits that assert claims of liability for harm done to the corporation, whether through neglect, insufficient oversight, or waste or misappropriation of corporate assets; and, on the other hand, cases (which we refer to as "deal cases”) that challenge the validity of transactions (primarily mergers) that involve the acquisition or conversion of publicly held shares. This categorization of derivative cases and deal cases may appear unfamiliar or inapt to students of the subject who more typically differentiate between derivative claims and direct, or individual, claims. We do not believe, however, that this categorization excludes any significant aspect of representative shareholder litigation. Although some such litigation involves direct claims not addressing any particular merger or acquisition, deal litigation constitutes the bulk of representative shareholder litigation under state corporate law that is not brought derivatively on behalf of the corporation. ${ }^{40}$ Conversely, we are not aware of any derivative suits challenging a transaction in which the

\footnotetext{
${ }^{40}$ Robert B. Thompson \& Randall S. Thomas, The New Look of Shareholder Litigation: Acquisition-Oriented Class Actions, 57 VAND. L. REV. 133, 135 (2004).
} 
shares of the plaintiff shareholder are being acquired, so there appears to be no overlap between derivative suits and what we identify as deal cases.

We return, then, to a description of the two principal forms of representative shareholder litigation in the public company. Cases complaining of harm to the corporation itself, where the relief sought is therefore typically a judgment for monetary damages in favor of the corporation, are brought as derivative suits. ${ }^{41}$ Those suits are therefore subject to the various requirements of Court of Chancery Rule 23.1, notably the requirement that a pre-suit demand be made on the board of directors, or that the allegations of the complaint establish that such demand is excused. In addition, such cases typically seek a monetary recovery on account of some action (or inaction where action was required) after it has occurred, and do not involve requests for preliminary injunctive relief. Therefore, in the absence of a request for preliminary injunctive relief, it is the motion to dismiss, and not the motion to expedite discovery, that plays the most important role in determining which derivative suits are permitted to proceed toward discovery and trial.

In contrast, deal cases involve claims of impairment of the stockholders' shares, and any monetary award redounds to the benefit of the stockholders themselves rather than the corporation. These cases therefore are brought by stockholders asserting individual (or direct) claims, rather than derivative claims on behalf of the corporation. Accordingly, they are not subject to Rule 23.1, and are evaluated using the generally applicable rules of civil procedure. In the case of deals involving publicly traded companies, these cases are typically brought as class

\footnotetext{
${ }^{41}$ E.g., Tooley v. Donaldson, Lufkin \& Jenrette, Inc., 845 A.2d 1031, 1036 (Del. 2004) ( a derivative suit "enables a stockholder to bring suit on behalf of the corporation for harm done to the corporation. Because a derivative suit is being brought on behalf of the corporation, the recovery, if any, must go to the corporation.”).
} 
actions. ${ }^{42}$ Notably, however, and unlike the typical derivative suit, deal cases frequently involve a request for preliminary injunction against the transaction, and are accompanied at the outset by a motion to expedite discovery in aid of the application for a preliminary injunction. Thus, courts in this situation typically do not have the opportunity, before substantial discovery costs have been incurred, to engage in a formal evaluation of whether to dismiss the litigation. Accordingly, in deal cases involving motions for a preliminary injunction, the primary occasion to evaluate whether discovery costs should be incurred is the motion to expedite discovery - a procedural context that has therefore taken on a significant efficiency-policing role, in the form of increasingly rigorous assessment of whether the asserted claims are "colorable" - i.e., whether the available facts indicate that they have substantive merit. ${ }^{43}$

${ }^{42}$ Daines, note [ ] above (studying litigation challenging M\&A transactions and finding that lawsuits filed by shareholders of large U.S. public target companies usually take the form of class actions).

${ }^{43}$ See Part III.C. 
Working Paper - draft of 8-19-15

\section{THE PROCEDURAL FOUNDATIONS OF PLEADING STAGE EVALUATION}

Derivative suits and deal cases in the Delaware courts both proceed under a set of procedural rules and doctrines that are indispensable to the operation of the triage system that we examine. These rules and doctrines serve three interrelated purposes: first, they promote the availability of relevant information at the pleading stage so that the information gap between that stage and trial is reduced; second, they otherwise advance the informational function of the disposition at the pleading stage, in the sense that they increase the value of the pleading stage determination as a predictor of the ultimate outcome at trial and, thus, as a basis for encouraging voluntary settlements; and finally, they promote the cost-saving function of pleading stage evaluation by avoiding costs that would otherwise be incurred in proceeding to trial.

\section{A. Information Gap-Reducing Measures}

It is a common lament that it is difficult for courts to assess whether litigation is meritorious at the pleading stage, before discovery has occurred. ${ }^{44}$ It may be particularly difficult to make such an assessment where the relevant facts are primarily within the possession and control of the defendants. ${ }^{45}$ That asymmetry is typical of the shareholder/management

\footnotetext{
${ }^{44}$ See, e.g., James J. Park, Rules, Principles, and the Competition to Enforce the Securities Laws, 100 Calif. L. Rev. 115, 175 (2012) (“Assessing the merits is an inherently difficult task, not because the courts do not have expertise that the SEC has, but because at the screening stage before discovery, the facts are undeveloped.”); Michael J. Kaufman \& John M. Wunderlich, The Unjustified Judicial Creation of Class Certification Merits Trials in Securities Fraud Actions, 43 U.MiCH.J.L. REFORM 323, 372 (2010) (“'Neither defendants nor plaintiffs could adequately assess the strength of their own claim or their opponent's claim absent discovery requests.' [citation omitted] And neither can the court adequately assess the strength of the claims absent discovery."); Geoffrey Edwards, Comment: Preemption Gone Wrong: Reconsidering ERISA Preemption of Wrongful Termination Claims in the Ninth Circuit, 32 U.C. DAVIS L. REV. 1079, 1096 (1999) ("At the removal stage, the parties have usually not conducted any discovery. [citation omitted] Thus, the court has no evidence with which to judge the plausibility of the plaintiff's complaint.");

${ }^{45}$ See Stancil, note [ ] above, at 92 ("An informational asymmetry favoring defendants over plaintiffs drives a preference for liberal pleading standards. That is, the typical defendant often
} 
relationship in general, given the centering of managerial responsibility in the board of directors, and the relatively limited informational rights accorded to shareholders. ${ }^{46}$ In these circumstances, it might be natural to conclude that courts would be particularly ill-equipped to assess the merits of shareholder litigation at the pleading stage, before the shareholder has had an opportunity, through discovery, to overcome the informational disadvantage described above.

That informational disadvantage, however, may be overstated, at least as it relates to the courts' ability to assess the merits of shareholder litigation at the pleading stage. In the numerous ways described below, the Delaware system helps fill in informational gaps at that stage, making the motion to dismiss a meaningful and generally fair tool for promoting efficiency in shareholder litigation.

\section{Mechanisms of Pleading Stage Access to Information}

Although stockholders’ information rights are limited, they are not a null set: by statute, stockholders have basic rights to inspect corporate books and records. ${ }^{47}$ And where the Delaware courts have found shareholder complaints lacking in detailed factual content, they have repeatedly admonished the plaintiffs to use the "tools at hand" - principally statutory inspection rights - to elicit information sufficient to determine the merits of a claim. ${ }^{48}$ A virtue of this

has sole possession of relevant information, and plaintiffs often cannot know critical details of their claims before discovery.”).

${ }^{46}$ Report of the Task Force of the ABA Section of Business Law Corporate Governance Committee, 65 Bus. LAW. 107, 113, 116, 118 (2009) (“Control of, and responsibility for, the business and affairs of the corporation is vested in the board of directors, rather than in the company's shareholders;" and shareholders have "key but limited rights," including "significant information rights.”).

${ }^{47}$ E.g., tit. 8, DEL. CODE ANN. $§ 220$ (permitting stockholder inspection of corporate books and records for a "proper purpose.”).

${ }^{48}$ Ash v. McCall, 2000 Del. Ch. LEXIS 144 n. 56 (Del. Ch. Sept. 15, 2000) ("As the Delaware Supreme Court has repeatedly exhorted, shareholder plaintiffs should use the 'tools at hand,' most prominently $\S 220$ books and records actions, to obtain information necessary to sue 
system is that it is tailored to avoid the enormous costs of the broad discovery available in litigation under generally applicable rules of procedure: unlike discovery under Rule $26,{ }^{49}$ inspection requests must be ““"circumscribed with rifled precision,” ${ }^{0}$ and stockholders are entitled to inspect only those corporate records that are "essential and sufficient” or "necessary and essential” to the stockholder's purpose for inspection. ${ }^{51}$ Despite these scope limitations, the statutory inspection right has enabled stockholder plaintiffs to gain access to facts sufficient to support pleadings that can overcome a motion to dismiss. ${ }^{52}$

Although the statutory inspection right is an important tool for enabling the motion to dismiss to serve as a useful predictor of ultimate outcomes after trial, there are two important limitations on its utility for this purpose. First, it may require the outlay of substantial resources by both stockholders and corporations. Even though exercise of the right does not necessarily

derivatively."); Brehm v. Eisner, 746 A.2d 244 n. 57 (Del. 2000) ("Plaintiffs have the opportunity to use the "tools at hand" to learn facts relating to Crystal's report and the Board's consideration through an interview with Crystal or by seeking appropriate and precisely identified corporate records in a Section 220 proceeding.”).

${ }^{49}$ Like its counterpart in the Federal Rules of Civil Procedure, Chancery Court Rule 26(b)(1) provides that "[p]arties may obtain discovery regarding any matter, not privileged, which is relevant to the subject matter involved in the pending action," and that information may be sought if it "appears reasonably calculated to lead to the discovery of admissible evidence."

50 Sec. First Corp. v. U.S. Die Casting and Dev. Corp., 687 A.2d 563, 570 (Del. 1997).

${ }^{51}$ Kaufman v. CA, Inc., 905 A.2d 749, 753 (Del. Ch. 2006); Helmsman Mgmt. Servs., Inc. v. A\&S Consultants, Inc., 525 A.2d 160, 167 (Del. Ch. 1987).

52 The Disney litigation is a notable example of this: in that case, after a stockholder's initial complaint was dismissed, use of the statutory inspection right unearthed additional information sufficient to permit the filing of an amended complaint that overcame a motion to dismiss. In re Walt Disney Co. Derivative Litig., 825 A.2d 275, 279 (Del. Ch. 2003) (“After the Supreme Court's remand regarding plaintiffs' first amended complaint, plaintiffs used the 'tools at hand,' a request for books and records as authorized under 8 Del. C. § 220, to obtain information about the nature of the Disney Board's involvement in the decision to hire and, eventually, to terminate Ovitz. Using the information gained from that request, plaintiffs drafted and filed the new complaint,” which survived a motion to dismiss.). 
result in judicial proceedings, ${ }^{53}$ disputes frequently arise that require the expense of court proceedings to resolve issues like the propriety of the stockholder's purpose for inspection, whether the scope of the requested inspection is appropriate, and what limits on use of the information (confidentiality, for example) are appropriate. ${ }^{54}$ The second and related limitation is the time required for exercising the statutory inspection right. Again, in theory the right can be expeditiously utilized: the statute requires the corporation to respond to an inspection demand in a week, and the courts treat proceedings to enforce inspection rights as summary in nature, justifying expedited procedures. ${ }^{55}$ As a practical matter, however, contested demands for

53 The governing statute requires only that the stockholder make and deliver to the corporation a written demand under oath stating a proper purpose for inspection, and the corporation is required to provide the appropriate records within five business days. Tit 8, DEL. CODE ANN. $\S 220(c)$.

${ }^{54}$ E.g., CM \& M Grp., Inc. v. Carroll, 453 A.2d 788, 792 (Del. 1982) ("The Court of Chancery is to determine the propriety of the purpose from the facts in each case.”); Thomas \& Betts Corp. $v$. Leviton Mfg. Co., 681 A.2d 1026, 1035 (Del. 1996) ("the trial court has wide latitude in determining the proper scope of inspection.”; Sahagen Satellite Tech. Grp. v. Ellipso, Inc., 791 A.2d 794, 794 (Del. Ch. 2000) (Plaintiff's right of inspection under § 220 depended on the propriety of his stated purpose, which the court found was proper. But plaintiff failed to meet its burden of proving, by a preponderance of the evidence, a credible basis for the wide-ranging request. The court therefore ordered a limited inspection.); Jefferson v. Dominion Holdings, Inc., 2014 Del. Ch. LEXIS 184, *3 (Del. Ch. Sept. 24, 2014) (“Confidentiality agreements provide a rational, reasonable, and enforceable methodology for dealing with corporate books and records that otherwise would not be subject to public review.”).

55 Tit 8, DEL. CODE ANN. §220(c) (“The Court may summarily order the corporation to permit the stockholder to inspect the corporation's ... books and records ... .; Quantum Tech. Partners IV, L.P. v. Ploom, Inc., 2014 Del. Ch. LEXIS 78, *24 (Del. Ch. May 14, 2014) (after refusal by the corporation to permit the requested inspection, "the stockholder may petition this Court in a summary proceeding to compel such inspection.”); Loppert v. Windsortech, Inc., 865 A.2d 1282, 1290 (Del. Ch. 2004) ("[T]he 220 Action was proceeding at an expeditious pace because actions under 8 Del. C. § 220 are summary in nature.”); Troy Corp. v. Schoon, 959 A.2d 1130, 1136 (Del. Ch. 2008) ("summary nature of 220 actions.”); Scattered Corp. v. Chi. Stock Exch., 671 A.2d 874, 879 (Del. Ch. 1994) ("stockholders of stock corporations are entitled to enforce their inspection rights under the streamlined, summary procedures afforded by $\S 220$ ”). 
inspection often require a fair amount of time to resolve, ${ }^{56}$ and this limits their utility in shareholder litigation in two notable ways: first, there is often pressure on stockholder plaintiff lawyers to forgo use of statutory inspection rights when even a relatively short delay will give a first-filing advantage to a less diligent plaintiff's lawyer; ${ }^{57}$ second, where preliminary injunctive relief is sought (most typically in deal litigation), even relatively expeditious litigation to enforce statutory inspection rights will not generate information in a timely way.

These limitations on the utility of the statutory inspection right are greatly mitigated, at least for public companies, by the disclosure regime under the federal securities laws. Unlike the state inspection right, those laws generate information for stockholders (and others) at no direct incremental cost, and with no need to request or demand the information. The informational requirements of the federal disclosure system, moreover, address actions and transactions that are the most likely targets of representative shareholder litigation. Among other things, they expressly require ongoing disclosure of related party transactions, ${ }^{58}$ as to which judicial scrutiny is most likely to be enhanced, and extensive disclosures concerning merger proposals, through

56 See e.g., Wal-Mart Stores, Inc. v. Ind. Elec. Workers Pension Trust Fund IBEW, 95 A.3d 1264 (Del. 2014) (demand made June 6, 2012; suit filed August 13, 2012; depositions in fall 2012; final hearing on May 20, 2013; appeal decided July 23, 2014); Frank Reynolds, Delaware judge finds Wal-Mart produced all missing documents, ending long records battle, (May 8, 2015) available at http://blog.thomsonreuters.com/index.php/delaware-judge-finds-wal-mart-producedall-missing-documents-ending-long-records-battle/ (describing the ruling ending "a nearly threeyear-long books-and-records battle with a shareholder investigating bribery at Wal-Mart’s Mexican subsidiary.”).

57 See Strine, et al., note [ ] above, 69 Bus. LAw. at 18 ("Plaintiffs' counsel who opts for investigation and deliberation may find herself the 'loser' under rules of jurisdictional priority that favor the first-filed lawsuit.”).]

58 See 17 CFR 229.404 (Item 404)(a) (requiring narrative disclosure of “material” related party transactions); 17 CFR 229.407 (Item 407)(a)(3) (requiring disclosure of all related party transactions, material or not, with its "independent" directors to ensure those transactions do not impair the directors’ exercise of independent judgment); 17 CFR 229.402 (Item 402) (requiring disclosure of executive compensation). 
current reports on Form 8-K, proxy statements and public responses to tender offers. Thus, even without a state law right of inspection, stockholders have considerable informational resources with respect to publicly held companies and the most likely targets of shareholder litigation. ${ }^{59}$

In deal cases there is often an additional potential source of information from which a class action complaint can be enriched with factual specificity: in cash acquisitions, the appraisal remedy is typically available, and a petition seeking appraisal need not lay out a claim of director or controlling stockholder misconduct in order to permit discovery to proceed. To be sure, discovery through appraisal proceedings, as with the statutory inspection right, requires a significant investment of time and effort, and its informational yield is likely to come too late to facilitate formulation of a complaint in an expedited matter in which a preliminary injunction is sought. It is undoubtedly useful, however, at least occasionally, as a source of information for complaints seeking monetary damages after a deal has closed. ${ }^{60}$ Indeed, there have been

${ }^{59}$ In contrast, shareholder suits alleging lack of care or failure of oversight are likely to involve sources of relevant information that are not readily available to the public (for example, board meeting minutes or other documents reflecting internal deliberations). That lack of readily available information makes pursuit of such claims more difficult, and makes the system of pleading stage triage studied in this Article more likely to result in occasional dismissals of suits that might prove to have merit if full discovery were permitted. No system can achieve perfect results in all cases, however, and some agency costs are irreducible. Michael C. Jensen \& William H. Meckling, The Theory of the Firm: Managerial Behavior, Agency Costs and Ownership Structure, 3 J. Fin. ECON. 305 (1976). But claims of lack of care or failure of oversight are rarely successful, even with the benefit of full access to relevant information. See, e.g., Brehm v. Eisner (In re Walt Disney Co. Derivative Litig.), 906 A.2d 27 (Del. 2006) (applying the business judgment rule to validate executive compensation, after extensive discovery and a 37-day trial). Thus, a system that sought to rectify informational asymmetry in regard to claims of director negligence or oversight failure could impose greater costs than the rare benefits it might achieve.

${ }^{60}$ See Virtus Capital L.P. v. Eastman Chem. Co., 2015 Del. Ch. LEXIS 34, *29 (Del. Ch. Feb. 11,2015 ) (noting that plaintiff's complaint alleging breach of fiduciary duty was based on information derived from discovery in a previously filed statutory appraisal proceeding). The court pointedly noted that, while dismissal was sought based on claimed lack of personal jurisdiction, "[n]one of the defendants have moved to dismiss the complaint for failing to state a claim on which relief could be granted.” Id. at *2-*3. 
significant class action deal cases that have followed and been facilitated by previously commenced appraisal litigation. ${ }^{61}$

\section{2. $\quad$ Requiring Particularized Pleading}

As previously noted, litigation in the Delaware Court of Chancery is generally guided by the liberal "notice pleading” rules that are designed to avoid, rather than generate, a factually detailed evaluation of the strength of a case based solely on the formal pleadings. ${ }^{62}$ And where a "short and plain statement of the claim” suffices to proceed to discovery and trial, and a complaint may not be dismissed unless there is no "reasonably conceivable" 63 cause of action appearing from that "short and plain statement," the resulting concern is that shareholder plaintiffs' lawyers will exploit those burdens to extract settlements unrelated to the merits of the case - to the ultimate detriment of the shareholders whose interests are purportedly advanced by shareholder litigation. A plausible response to that concern could be a greater insistence that, as a

${ }^{61}$ E.g., Cinerama, Inc. v. Technicolor, Inc., 1991 Del. Ch. LEXIS 105, *2 (Del. Ch. June 21, 1991), rev'd on other grounds, 634 A.2d 345 (Del. 1993) ("During the course of the pretrial phase of that appraisal proceeding, plaintiff developed testimony apparently leading it to the belief that misconduct had occurred in the sale of the company.”).

${ }^{62}$ Part I.B above.

${ }^{63}$ By reversing a dismissal that adopted the developing federal requirement that the complaint demonstrate a "plausible" cause of action, the Delaware Supreme Court has appeared to adopt a more permissive approach to pleading. Central Mortgage Co. v. Morgan Stanley Mortgage Capital Holdings LLC, 27 A.3d 531, [ ] (Del. 2011). (rejecting the "plausibility" standard articulated in Bell Atlantic Corp. v. Twombly, 550 U.S. 544, 556 (2007), finding it "higher" than the "reasonable 'conceivability"” standard adopted by the Delaware Supreme Court. We suggest, however, that Central Mortgage's articulation of a distinction from the Twombly standard has little if any substance, given the adoption of the requirement that a cause of action be "reasonably" conceivable - not "outlandishly" or "speculatively" conceivable - from the specific factual allegations of the complaint. 
prerequisite to going forward with discovery, complaints demonstrate a more detailed factual basis for the claims they assert. ${ }^{64}$

And indeed, that is precisely the procedural approach that the Delaware courts have adopted. We detail more fully below how this approach has developed, in both derivative suits and deal cases. ${ }^{65}$ In general, however, what we find are judicially developed requirements for pleading specific facts that would rebut the substantive deference to director conduct afforded by the business judgment rule. ${ }^{66}$ In representative shareholder litigation, particularized pleading is now the rule, notwithstanding the generally applicable "notice pleading” approach of the rules of civil procedure. As a result, shareholder plaintiffs' counsel are encouraged to provide in the complaint itself as extensive as possible a recitation of facts supporting their claims, a recitation that better enables the court to assess, on a motion to dismiss, the likely outcome if the case were ultimately tried.

3. Considering Facts Not Specifically Pleaded in the Complaint Encouraging factual specificity and particularity in formulating complaints has a significant collateral effect in Delaware shareholder litigation practice: allegations in the complaint that refer to or even just recite information contained in other documents may permit the defendants to supplement the factual basis for resolving the motion to dismiss by bringing to the court's attention other facts referred to in those other documents. Indeed, knowing that shareholder plaintiffs frequently rely in their complaints on documents, like a merger proxy statement or a special litigation committee report, to supply the requisite factual specificity about

\footnotetext{
${ }^{64}$ Stancil, note [ ] above, at 147 (where defendants disproportionately bear the costs of discovery, "it would be economically preferable if the default rule required the plaintiff to allege facts tending to support each element of her claim.”).

${ }^{65}$ Part III.B below.

${ }^{66} I d$.
} 
the challenged action or transaction, it may be prudent for transactional advisers to draft those documents with a view to presenting, rather than withholding for later disclosure, detailed facts about the corporate decision makers and the background of the transaction or decision. Using that approach, likely targets of shareholder litigation may be able to shape the "record" on the motion to dismiss in a way that enables the court to determine whether a majority of the board of directors is disinterested and independent, or to be able to access the full terms of a transaction, rather than a partial description of it in a complaint.

Two Delaware cases described below ${ }^{67}$ illustrate this approach to the motion to dismiss. But before examining those cases, it will be helpful to describe the foundation and evolution of the Delaware case law prescribing when facts not expressly pleaded in the complaint can be considered on a motion to dismiss. The "purist" approach to this subject begins with Court of Chancery Rule 12(b), which (in subsection (6)) provides for dismissal for failure to state a claim upon which relief can be granted, but importantly qualifies that provision by specifying that if "matters outside the pleading" are presented in support of the motion to dismiss, the motion is to be treated as one for summary judgment. ${ }^{68}$ The consequence of that treatment can be quite significant: under Court of Chancery Rule 56(f), a plaintiff can argue that discovery is necessary

67 Stone v. Ritter, 911 A.2d 362 (Del. 2006); Morton's Rest. Grp., Inc., 74 A.3d 656 (Del. Ch. 2013).

${ }^{68}$ Specifically, Rule 12(b) provides in relevant part:

If, on a motion asserting the defense numbered (6) to dismiss for failure of the pleading to state a claim upon which relief can be granted, matters outside the pleading are presented to and not excluded by the Court, the motion shall be treated as one for summary judgment and disposed of as provided in Rule 56, and all parties shall be given reasonable opportunity to present all material made pertinent to such a motion by Rule 56 . 
in order to respond adequately to the factual matters presented by the defendants "outside the pleading." 69

Obviously, the efficiency promoting function of the motion to dismiss could be largely eliminated if (1) every fact referred to by a defendant on a motion to dismiss converted the motion into one for summary judgment and (2) full discovery on the merits, and its attendant costs, were to ensue as a result. Nevertheless, the Delaware Supreme Court at one time expressed a fairly stringent view that indeed, every reference by a defendant on a motion to dismiss to any fact not specifically alleged in the complaint does convert the motion to one for summary judgment. In Malpiede v. Townson, ${ }^{70}$ discussed in more detail below, the court in 2001 addressed a motion to dismiss that relied in part on an exculpatory charter provision pursuant to section 102(b)(7) of the Delaware General Corporation Law. ${ }^{71}$ Perhaps eager to avoid inviting discovery by openly presenting that provision formally through an affidavit, the defendants simply referred to it in their brief on the motion to dismiss, even though the complaint itself, not surprisingly, made no reference to it.

${ }^{69}$ Rule 56(f) provides in relevant part:

Should it appear from the affidavits of a party opposing the motion that the party cannot for reasons stated present by affidavit facts essential to justify the party's opposition, the Court may refuse the application for judgment or may order a continuance to permit affidavits to be obtained or depositions to be taken or discovery to be had or may make such other order as is just.

70780 A. 2d 1075 (Del. 2001). See also In re Santa Fe Pac. Corp. S'holder Litig., 669 A.2d 59, 68-69 (Del. 1995) (ruling that even though the trial court may consider a proxy statement to determine, in evaluating nondisclosure claims, what the document actually stated, "[t]he Court of Chancery should not have considered the assertions in the [proxy statement] in support of defendants' motion to dismiss the Revlon and Unocal claims," because "If the [proxy statement] were relied upon for the truth of the matters contained therein, it would be hearsay with respect to claims other than the disclosure claims.”).

71 Tit. 8, DEL. CODE ANN. § 102(b)(7) (permitting a provision in the certificate of incorporation that limits or eliminates monetary liability of directors for breach of duty, with limited exceptions including breach of the duty of loyalty or conduct not in good faith). 
The Delaware Supreme Court recognized the gambit and applied Rule 12(b) literally: it insisted that the presentation of the provision converted the motion into a motion for summary judgment, "by clear force of the pleading rules."72 The court qualified that insistence, however, in two important ways: first, it suggested that the charter provision might have been taken into consideration on the motion to dismiss, without creating an opening for discovery, if the defendants had requested that the trial court take judicial notice of the provision, which was embodied in a public record. ${ }^{73}$ More importantly, the court recognized that just because the defendants proffer a fact outside the complaint, "it does not follow that the 'floodgates of discovery’ have to be opened. The Rule 56 opportunity to present affidavits or engage in discovery is not absolute."74 Noting that the plaintiffs did not contest the authenticity or validity of the charter provision, the court concluded that "the plaintiffs were not deprived of any important procedural right arising from the fact that the trial court considered [the] 102(b)(7) charter exculpation provision in connection with the Rule 12(b)(6) motion to dismiss.”75

In the fifteen years since Malpiede was decided, the Delaware courts have developed a number of approaches, in addition to judicial notice, enabling them to consider unpleaded facts in deciding motions to dismiss for failure to state a claim, without "opening the floodgates of discovery." ${ }^{76}$ For example, if a complaint attaches a document, the court may consider the

\footnotetext{
72780 A.2d at 1092.

${ }^{73}$ Id. at 1090 (noting that the provision "could easily be found in the public files in the Secretary of State's office and could properly be noticed judicially by the court”).

${ }^{74}$ Id. at 1091.

${ }^{75}$ Id. at 1092.

76 This inventory of approaches is drawn from In re Morton's Rest. Grp., Inc., 74 A.3d 656, 658 nn. 3-4 (Del. Ch. 2013), discussed more fully below, which helpfully collects the Delaware cases employing them.
} 
Working Paper - draft of 8-19-15

assertions in that document in resolving a motion to dismiss. ${ }^{77}$ And even if a document is not attached as an exhibit to the complaint, the court may consider it on a motion to dismiss if the complaint refers to it and substantially includes facts drawn from the document. ${ }^{78}$

The Delaware Supreme Court’s 2006 opinion in Stone v. Ritter, far better known for its affirmation of Caremark standards for assessing the directors’ oversight responsibilities, nicely illustrates how the Delaware courts have come to handle use of extrinsic material on motions to dismiss. The core claim in that case was that the directors had acted in bad faith by failing to take steps to implement a Bank Secrecy Act (BSA) compliance and reporting system. In their complaint, the plaintiffs "explicitly incorporated by reference into their derivative complaint" 79 a report prepared for the company by KPMG assessing the company's BSA compliance. Plaintiffs also included in the appendix to their brief on the motion to dismiss a board-adopted policy on BSA compliance, which the plaintiffs had obtained in response to a demand for inspection under

${ }^{77}$ DeLuca v. AccessIT Grp., Inc., 695 F. Supp. 2d 54, 60 (S.D.N.Y 2010) ("Pleadings include not just the four corners of the complaint, but also any written instrument attached to it as an exhibit or any statements or documents incorporated in it by reference.”).

${ }^{78}$ Freedman v. Adams, 2012 Del. Ch. LEXIS 74, *16 (Del. Ch. Mar. 30, 2012) ("When a plaintiff expressly refers to and heavily relies upon documents in her complaint, these documents are considered to be incorporated by reference into the complaint[.]"); In re Tyson Foods, Inc. Consol. S'holder Litig., 2007 Del. Ch. Lexis 120, *5-6 (Aug. 15, 2007) (“A plaintiff may not base a claim upon a contract or similar document, describe that contract in its complaint, but prevent a court from reviewing the plain terms of that agreement by omitting the document from the complaint itself. Such a rule would promote the crafting of misleading complaints containing strategic omissions.”); e4e, Inc. v. Sircar, 2003 Del. Ch. LEXIS 119, *9 (Del. Ch. Oct. 9, 2003) (concluding that the court could consider a letter not attached to the complaint because "the wrongful conduct alleged to have been engaged in by [the defendant] was taken directly from that . . letter"); White v. Panic, 783 A.2d 543, 547 n.5 (Del. 2001) (approving use of facts recited in a newspaper article, where "the plaintiff affirmatively placed the facts in the article before the Court of Chancery by attaching the full text of the article to his answering brief opposing the defendants' motion to dismiss. By doing so without any express limitation on the court's use of the document, the plaintiff acquiesced in the court's consideration of the entire article in deciding the motion to dismiss.”).

${ }^{79}$ Id., 911 A.2d at 372. 
DGCL Section $220{ }^{80}$ In that circumstance, the court found it appropriate to examine and rely on the entirety of the KPMG report and the BSA policy, concluding that those documents "reflect[] that the directors not only discharged their oversight responsibility to establish an information and reporting system, but also proved that the system was designed to permit the directors to periodically monitor [the company's] compliance with the BSA and [anti-money laundering] regulations." 81

Perhaps the high water mark for use of facts not directly pleaded in the complaint was the Court of Chancery’s 2013 opinion in Morton's Restaurant Group, Inc. ${ }^{82}$ In that case, perhaps the least controversial step was the court's reliance on management's tender offer recommendation statement, from which the complaint drew "pervasive references." ${ }^{83}$ More remarkably, the court also indicated that it could consider the content of depositions taken in the matter, because they “must be considered as fully incorporated into the Complaint given the plaintiffs' extensive use of them." 84

Obviously, the more extensive the courts' willingness to consider a record of facts outside the complaint in resolving a motion to dismiss, the more the motion to dismiss begins to

\footnotetext{
${ }^{80} \mathrm{Id}$.

${ }^{81} \mathrm{Id}$. at $371-372$.

82 Note [ ] above.

${ }^{83} I d ., 74$ A.3d at 659.

${ }^{84} I d$. at 658. The court explained as follows its willingness to rely on the depositions:
}

Here, the plaintiffs have relied on the four depositions, which they took in conjunction with these proceedings, to construct their Complaint, citing them 28 times. Those substantial references, which include selective quotations, incorporated the depositions by reference. Where, as here, there is no concern that the plaintiffs would not have notice that the defendants would want to put those selective quotations in context, the exceptions to the general rule that extraneous evidence should not be considered have particular force.

Id. n. 3. The court ultimately concluded, however, that it was unnecessary to rely on the depositions. 
serve the same function as a motion for summary judgment: namely, as a substitute for a trial, where dispositive facts are not reasonably in dispute. ${ }^{85}$ In fact, the Delaware Court of Chancery’s increasingly muscular reliance on extrinsic facts in resolving motions to dismiss demonstrates that the motion to dismiss is being increasingly relied upon as an efficiency-promoting substitute for a trial, in which, despite the absence or paucity of formal discovery, the court is able to rely on a reasonably substantial factual record, at least where (1) there is no indication or assertion by the plaintiff that information presented from outside the four corners of the complaint is disputable in a relevant way; and (2) substantial relevant information is available through publicly available sources, stockholder inspection rights, or voluntary production by the corporation.

\section{B. Measures to Improve the Predictive Value of Pleading Stage Evaluation}

In the previous section we examined aspects of Delaware's procedural system that are designed to promote an evaluation of pleadings in representative shareholder litigation that is more fully factually informed than one would normally encounter under generally applicable rules of civil litigation. In this section we examine other aspects of Delaware's procedural system that facilitate the exploitation of that richer factual base at the pleading stage. These aspects share the common purpose of improving the reliability of the decision on the motion to dismiss as a predictor of the outcome at trial. The more reliable and transparent the prediction, the greater the likelihood of a voluntary settlement and the avoidance of additional litigation costs.

\section{Judicial Assignment}

Cases in the Delaware Court of Chancery are assigned to the same chancellor for their duration: litigants know that the same judge who decides the motion to dismiss will (barring

${ }^{85}$ Crawford-El v. Britton, 523 U.S. 574, 600 (1998) ("[S]ummary judgment serves as the ultimate screen to weed out truly insubstantial lawsuits prior to trial."). 
retirement) preside over any trial to be held in the case. ${ }^{86}$ Thus, an opinion rendered on the motion to dismiss will reflect the assessment and likely attitude of the judge who will render the decision after trial (there being no jury in proceedings in the Court of Chancery). This practice eliminates most of the uncertainty arising where denial of a motion to dismiss is followed by proceedings in which a different decision-maker (a different judge, or a jury), whose likely assessment of the case is then largely unknown, takes control of the decision-making process. ${ }^{87}$ This practice also eliminates any incentive on the part of the pleading stage judge to disfavor dismissal in the hopes of avoiding reversal while being able to reduce workload by passing off the case to a judicial colleague.

\section{Disposition of Motions to Dismiss}

In addition to the predictive value added by assigning a case to a single judge, the Delaware system provides several other mechanisms that promote the predictive value of the disposition of motions to dismiss. First, motions to dismiss are almost always decided on the basis of extensive, reasoned written opinions. ${ }^{88}$ The importance of this practice can hardly be overstated. An explanation of the reasons for a dismissal is a signal to plaintiffs' lawyers and

\footnotetext{
86 1-1 Donald J. Wolfe, JR. \& Michael A. PitTenger, CoRp \& COMmERCiAl PraCtice in the DELAWARE COURT OF CHANCERY $\S 1.05$ ("Cases brought in the Court of Chancery are assigned to a specific Chancellor or Vice Chancellor from the outset.”).

${ }^{87}$ See Report of the South Carolina Bar's Task Force on Courts re: The Creation of a Business Court Pilot Program (Aug. 1, 2007) at 2 (“The current case-assignment system for civil matters in South Carolina does not lend itself to the prompt and efficient resolution of traditional business disputes. For example, Circuit Court judges who are assigned to a case at the beginning of the matter are not required to stay with that case until its final resolution. In a business dispute, the reassignment of a new judge in the middle of a lawsuit requires the parties to expend additional resources re-educating a new judge on what is often complex subject matter.”).

${ }^{88}$ State of Delaware, Litigation in the Delaware Court of Chancery and the Delaware Supreme Court, available at http://corplaw.delaware.gov/eng/litigation.shtml ("all cases are decided by the Chancellor or a Vice Chancellor, who explain their decisions in comprehensive and reasoned written opinions. The Court of Chancery's tradition of written opinions stretches back more than a hundred years.”).
} 
transactional advisers about what sort of suits to bring and not bring in the future, and how transactions should be structured to minimize the risk of litigation. ${ }^{89}$ In addition, a reasoned written opinion denying a motion to dismiss alerts the parties to the court's analysis of the case in a way that, much more than a terse grant or denial of the motion, illuminates the likely ultimate outcome of the case and better enables the parties to settle the case without having to expend the extensive resources necessary to try the case. The Delaware Court of Chancery is by no means the only trial court in the nation to render substantial written opinions on motions to dismiss, but not all courts follow this practice, ${ }^{90}$ and the regularity and extent of the Delaware courts' commitment to the practice is a substantial element of its system for dealing with and maximizing the value of motions to dismiss.

Delaware's experience with dismissal practice has also resulted in the development of a significant body of rules that clarify and improve the operation of that practice. For example, the Court of Chancery in 2001 adopted a unique rule ${ }^{91}$ that strongly encourages plaintiffs' counsel to withdraw or amend a complaint if the defendants' opening brief in support of a motion to dismiss appears persuasive. Specifically, the rule provides that if a plaintiff continues to resist a motion to dismiss and fails to amend its complaint promptly after reviewing the defendants'

${ }^{89}$ Id. ("The quantity and quality of the Court of Chancery's opinions confer a substantive advantage on Delaware business entities by providing them with a thorough and predictable body of interpretive case law. Managers and lawyers of Delaware business entities can use this extensive case law to guide in planning their business and affairs.”).

${ }^{90}$ See, e.g., Andrew R. Jones, Note: Toward A Stronger Economic Future For North Carolina: Precedent And The Opinions Of The North Carolina Business Court, 6 ElON L. REV. 189, 193194 (2014) (in North Carolina, "[n]on-Business Court trial courts enter short orders upon the disposition of matters before them, typically drafted by one of the attorneys appearing before the court, exchanged with opposing counsel, and submitted for the presiding judge to sign. In civil bench trials, and in other select circumstances, these orders must contain findings of fact and conclusions of law. Detailed findings of fact and conclusions of law are generally not required in other trial court orders.”).

${ }^{91}$ Court of Chancery Rule 15(aaa). 
opening brief, and the motion is subsequently granted, the dismissal is with prejudice, and, absent good cause, prevents further attempts to amend the complaint. A plaintiff is thus encouraged to put the "best foot forward" in resisting the motion to dismiss, providing some assurance that the complaint will take maximum advantage of available facts before the motion to dismiss is decided. ${ }^{92}$

\section{Cost-Avoidance Measures}

Despite these procedural rules and doctrines, the motion to dismiss would fail to perform its efficiency promoting function if the full costs and burdens of litigation were not substantially avoided while the motion is pending. Accordingly, a system that relies effectively on the motion to dismiss as a triage tool must include a strong preference to stay discovery pending the outcome of motions to dismiss. And indeed, that strong preference is clearly manifested by the Delaware Court of Chancery. In representative shareholder litigation in that court, a stay of discovery pending disposition of a motion to dismiss, while not quite automatic, is at the very least routine.

In fact, the Delaware courts have explicitly identified efficiency as a function of the motion to dismiss, and that a stay of discovery is necessary to achieve that efficiency:

[E]fficiency is promoted by the rule that, absent special circumstances, discovery will be stayed pending determination of a motion to dismiss where the ground for the motion offers a reasonable expectation that if the motion is granted litigation in this or another forum will be avoided. ${ }^{93}$

92 Zucker v. Andreesen, 2012 Del. Ch. LEXIS 135, 34 (Del. Ch. June 21, 2012) (granting motion to dismiss derivative action, and invoking Rule 15(aaa), rejecting plaintiff's reliance on a special committee report that could have been, but was not, included in the pleadings via an amended complaint).

${ }^{93}$ Wallace v. Durwood, 1993 Del. Ch. LEXIS 239, 9 (Del. Ch. Nov. 1, 1993), quoting In re McCrory Parent Corp., 1991 Del. Ch. LEXIS 112, Del. Ch., Cons. C.A. No. 12006, slip op. at 2, (July 3, 1991). 
Consistent with this view, the Delaware cases indicate that "[o]rdinarily, where a motion to dismiss is made a Court will direct that discovery be held in abeyance in the absence of a showing of a need that the discovery continue because it is always desirable to avoid the cost and inconvenience of unnecessary discovery." ${ }^{94}$ Of course, there is no rule in the Delaware courts that the filing of a case-dispositive motion automatically requires that discovery be stayed; conversely, the concept of staying all discovery pending resolution of a motion to dismiss (under Rule 23.1 in derivative suits, or Rule 12(b)(6) in other litigation) is not unique to Delaware. ${ }^{95}$ But the Delaware courts' seemingly ready acceptance of such requests to stay discovery is an important predicate for the use of the motion to dismiss as an efficiency-promoting procedure.

\section{PLEADING-STAGE EVALUATION OF REPRESENTATIVE SHAREHOLDER LITIGATION.}

The foregoing complex and highly evolved procedural framework for pleading-stage triage is only half the story, however: that framework is merely the vehicle by which substantive standards of review are applied. To fully appreciate the operation of the Delaware triage system, it is necessary to examine the evolution of the courts' willingness to engage in substantive review of the merits of the case at the pleading stage, and before significant discovery occurs. We trace below how that willingness emerged, first and most clearly in derivative litigation, and then in deal cases challenging transactions ranging from the most clearly legally defensible to

\footnotetext{
${ }^{94}$ Weinberger v. Amstar Corp., 1984 Del. Ch. LEXIS 445, *2 (Del. Ch. Jan. 16, 1984)

95 See, e.g., Mann v. Brenner, 375 F. App'x 232, 239 (3d Cir. 2010) ("In certain circumstances it may be appropriate to stay discovery while evaluating a motion to dismiss where, if the motion is granted, discovery would be futile.”); Kevin J. Lynch, When Staying Discovery Stays Justice: Analyzing Motions To Stay Discovery When A Motion To Dismiss Is Pending, 47 WAKE FOREST L. REV. 71 (2012) (reviewing approaches for determining when to grant a stay of discovery pending disposition of a motion to dismiss).
} 
transactions to which the most stringent form of judicial scrutiny (“entire fairness”) would initially apply.

\section{A. Aronson: Building the Triage System for Derivative Litigation}

We begin our treatment of pleading-stage evaluation of representative shareholder litigation with an appreciative assessment of Aronson v. Lewis, ${ }^{96}$ the Delaware Supreme Court's important 1984 decision that established the foundation for the modern system of triage in such litigation. In that case, the court addressed head on the fact that the governing rule of procedure (Chancery Court Rule 23.1) ${ }^{97}$ and its requirement of pre-suit demand on the board of directors had evolved to become toothless: a derivative complaint could always effectively avoid that requirement by using one or more "shorthand shibboleths" that would demonstrate that such a demand would be futile, in that directors who engaged in or approved the challenged conduct could not be expected to cause the corporation to sue themselves over that conduct. ${ }^{98}$

Practically ex nihilo, however, Aronson conjured a rule of dismissal that rendered pre-suit demand, and the literal text of Rule 23.1, essentially irrelevant: henceforth, whether a derivative suit would proceed would not depend on the outcome of some perfunctory pre-suit petitionary minuet between the stockholder plaintiff and the board of directors. Instead, such suits would

96473 A.2d 805 (Del. 1984); see also David A. Skeel, Jr., The Accidental Elegance of Aronson v. Lewis, in JONATHAN R. MACEY, ED., THE ICONIC CASES IN CORPORATE LAW 167 (Thomson West 2008) ("Aronson v. Lewis is nested deep within the longstanding effort to devise a framework that sensibly mediates between the competing concerns of encouraging meritorious litigation and screening out strike suits.”).

${ }^{97}$ Chancery Court Rule 23.1(a) provides in relevant part:

The complaint shall also allege with particularity the efforts, if any, made by the plaintiff to obtain the action the plaintiff desires from the directors or comparable authority and the reasons for the plaintiff's failure to obtain the action or for not making the effort.

${ }^{98}$ Aronson, 473 A.2d at 816 (concluding that in the demand-futile context a plaintiff charging domination and control of one or more directors must allege particularized facts and that the "shorthand shibboleth" of dominated and controlled directors is insufficient). 
proceed, or not, according to the court's own direct assessment of whether the allegations of the complaint indicate that the suit will be meritorious. ${ }^{99}$ The governing rubric, more specifically, is whether there is reasonable doubt that the board of directors lacked a disinterested, independent majority, or otherwise would not be protected by the business judgment rule. ${ }^{100}$ The first prong of this standard reinforced that the litigation engine would engage if a derivative plaintiff could plead that the relevant decision maker could not be trusted to have made a disinterested decision with regard to the challenged conduct. On top of that standard litmus test, the court grafted a second, more open-ended test, inviting the trial court to find in the complaint any other set of circumstances that would deprive the directors' decision of the traditional deference of the business judgment rule. That test introduced an opportunity for considerable judicial discretion, ${ }^{101}$ which the Delaware courts have frequently employed to decline to dismiss derivative litigation. ${ }^{102}$ With respect to stockholder derivative litigation, at least, Aronson gave the courts a doctrinal tool sufficient to rein in inefficient lawsuits and identify meritorious ones at the pleading stage.

99 See M. Todd Henderson, Essay: Justifying Jones, 77 U. CHI. L. REV. 1027, 1048 (2010) ("the Federal Rules of Civil Procedure do not obviously permit federal courts to weed out cases in the way that the Delaware Court of Chancery can. Delaware courts employ the demand requirement to give their expert judges a peek at the merits before discovery, and the Court of Chancery is known for dismissing cases quickly and at early stages of the litigation, as soon as it believes the merits can be evaluated.”).

${ }^{100}$ See In re Ebix, Inc. Stockholder Litig., Civil Action No. 8526-VCN, 2014 WL 3696655 (Del. Ch. July 24, 2014) (stating that in derivative suits a court must determine under Aronson whether, "under the particularized facts alleged, a reasonable doubt is created that: (1) the directors are disinterested and independent [or] (2) the challenged transaction was otherwise the product of a valid exercise of business judgment.”) (internal quotations omitted) (quoting Aronson, 473 A.2d at 814).

101 Grimes v. Donald, 673 A.2d 1207, 1217 n. 15 ("Judging whether demand is excused 'is inescapably a question of judgment....' [citation omitted] The exercise of discretion by experienced and capable judges is a satisfactory screening mechanism, in our view.”).

${ }^{102}$ Id. at 1217 n. 19 (collecting cases denying motions to dismiss under Rule 23.1) 


\section{B. Extending the Fact Pleading Approach to Other Cases}

The use of a fact pleading approach to litigation triage did not end, however, within the boundaries of Rule 23.1 and derivative litigation. In various ways described in this section, the Delaware courts have extended the fact pleading approach to a variety of settings in which the specific pleading particularity requirement of Rule 23.1 does not apply.

\section{Trifoods}

Former Chancellor Allen's 1996 decision in Gagliardi v. Trifoods Int'l, Inc. ${ }^{103}$ took the next step in extending the fact pleading approach by using it under the more generally applicable rule of civil procedure providing for dismissal, namely Rule 12(b)(6). ${ }^{104}$ Plaintiff Eugene Gagliardi was the founder of Trifoods. ${ }^{105}$ After he lost control of the board he was removed as board chair and his employment relationship was terminated, although he continued to own approximately $13 \%$ of the company's common stock. ${ }^{106}$ The new management group implemented a restructuring of the company which included buying assets, increasing spending on research, and moving the company's operations to a new state. ${ }^{107}$ Ordinarily, one would applaud a board's efforts to rethink and rejuvenate corporate strategy. But the strategy failed, and Gagliardi alleged that these new management initiatives caused an immediate, sharp deterioration in the business of the company. ${ }^{108}$

103683 A.2d 1049 (Del. Ch. 1996).

${ }^{104}$ Chancery Court Rule 12(b) provides in relevant part that "the following defenses may at the option of the pleader be made by motion: ... (6) failure to state a claim upon which relief can be granted ....”

105 Id., at 1050 .

${ }^{106} \mathrm{Id}$.

${ }^{107}$ Id., at 1051 . These actions formed the basis of plaintiff's negligent mismanagement claim.

${ }^{108}$ Id. at 1051. 
At its most cogent, the complaint alleged specific instances of what it called mismanagement and waste of corporate assets. And on a broad view what might have been “reasonably conceivable" - to use the appropriate pleading standard - the plaintiff could ultimately have adduced facts in discovery sufficient to demonstrate at trial that no person of sound judgment could rationally have considered the challenged actions to have been appropriate in the interests of the corporation and its stockholders. ${ }^{109}$ Given that reasonable conceivability, one could have argued that dismissal of the lawsuit, before discovery, would have been inappropriate.

But in a move that has never been criticized as an inappropriate application of Rule 12(b)(6), Chancellor Allen dismissed most of the mismanagement claims asserted in the complaint on the grounds that there were no allegations that those responsible for the challenged business conduct suffered from any disabling conflict of interest or improper motivation. ${ }^{110}$ He did so expressing concern that director liability for mismanagement alone would unduly discourage optimal risk-taking. ${ }^{111}$ Of course, he would have reached the same result even if he

\footnotetext{
${ }^{109}$ See In re MFW S'holders Litig., 67 A.3d 496, 526 (Del. Ch. 2013), citing Sinclair Oil Corp. v. Levien, 280 A.2d 717, 720 (Del. 1971) ("the business judgment rule standard of review ... precludes judicial second-guessing so long as the board's decision 'can be attributed to any rational business purpose.'”).

${ }^{110}$ Trifoods, 683 A.2d at 1053 (“Certainly these allegations state facts that, if true, constitute either mistakes, poor judgment, or reflect hard choices facing a cash-pressed company, but where is the allegation of conflicting interest or suspect motivation? ... There are none. Nothing is alleged other than poor business practices. To permit the possibility of director liability on that basis would be very destructive of shareholder welfare in the long-term.”).

${ }^{111}$ Id., at 1052-53 ("The law protects shareholder investment interests against the uneconomic consequences that the presence of such second-guessing risk would have on director action and shareholder wealth in a number of ways. It authorizes corporations to pay for director and officer liability insurance and authorizes corporate indemnification in a broad range of cases, for example. But the first protection against a threat of sub-optimal risk acceptance is the so-called business judgment rule. That "rule" in effect provides that where a director is independent and disinterested, there can be no liability for corporate loss, unless the facts are such that no person could possibly authorize such a transaction if he or she were attempting in good faith to meet their duty.” (citing Saxe v. Brady, Del.Ch., 184 A.2d 602 (1962)) (emphasis in original)).
} 
had allowed to the case to go to trial, as long as he ultimately applied the business judgment rule to preclude liability.

What he did as a practical matter, though, was different: rather than simply avoiding a finding of director liability after trial, he took the business judgment rule and applied it to avoid proceeding with litigation at all. In effect, what was a rule of substantive law was put to use as a pleading rule as well: as the Chancellor put it, "to allege that a corporation has suffered a loss as a result of a lawful transaction, within the corporation’s powers, authorized by a corporate fiduciary acting in a good faith pursuit of corporate purposes, does not state a claim for relief against that fiduciary no matter how foolish the investment may appear in retrospect.”112

The result was to eliminate the costs of going to trial by enhancing the "motion to dismiss" step in the litigation. And Chancellor Allen quite clearly described the rationale for this approach, in a passage addressing an assertion that "no reasonable business person would have engaged in” the transaction complained of:

Under the general notice pleading rules this conclusory addition to allegations that otherwise clearly fall within the ambit of the business judgment rule might perhaps be regarded as sufficient to proceed to discovery. ... But it is not clear that, where derivative claims are involved, good policy supports the same result. Asserting a derivative claim allows an attorney in the role of agent for shareholders to exert substantially magnified settlement pressure on a defendant. The risk/reward situation of the individual director defendants (discussed above), coupled with the ordinary workings of indemnification rights and insurance, means that very, very few derivative suits reach trial. Strike suits are a greater threat in this context than in civil litigation between two principals. Thus, in such cases the consequences of surviving a motion to dismiss are, as a practical matter, substantially more significant than in garden variety civil litigation.

It is rational and good policy for the law to filter such cases at an early stage more finely than the Rule 12(b)(6) test permits. This in effect can be done through the operation of Rule 23.1, which modifies the notice pleading standard by requiring plaintiff to plead with particularity either that plaintiff has sought to induce the board to bring the action

112 Trifoods, 683 A.2d at 1052 (emphasis added 
and that the board has failed or refused to do so for no good reason or the reason plaintiff has not sought the board's action. ${ }^{113}$

Chancellor Allen thus made many of the points that we noted above (although he did it about twenty years earlier): he acknowledged the asymmetry of costs of benefits of representative shareholder litigation as between defendants, on one hand, and plaintiffs and their counsel on the other; he acknowledge that this asymmetry magnifies the pressure that representative shareholder plaintiffs and their counsel are able to bring to bear; he acknowledged that, as a result of such pressure, strike suits are a greater threat than in cases involving two opposing principals; he acknowledged that the motion to dismiss therefore takes on a special importance, as a "filter," in the case of representative shareholder litigation; and, finally, he acknowledged that the pre-suit demand requirement of Rule 23.1 was particularly well suited to serve as such a "filter” (but relied on Rule 12(b)(6) anyhow).

The facts of the case made this major procedural change easy to accomplish. The plaintiff, as former board chair, had intimate knowledge of the corporation and its businesses. With the central facts known and undisputed at this stage in the proceeding, the court could easily conclude that the trial would accomplish nothing more than having the plaintiff allege in greater detail the foolishness of the new management's business strategy. Even if the plaintiff's claim could have been characterized as "conceivable," it could not satisfy the more demanding, subsequently articulated standard of being “reasonably conceivable.” ${ }^{114}$ Critical, however, to achieving this procedural jump was that the essential facts were already before the court at the motion to dismiss stage and that the court was experienced in evaluating complex business transactions.

\footnotetext{
${ }^{113}$ Id. at 1054 .

${ }^{114}$ Cent. Mortg., note [ ] above, 27 A.3d at 538 (emphasis added).
} 


\section{Caremark and Stone v. Ritter: Fact Pleading in Oversight Cases}

The approach taken by Chancellor Allen in Trifoods set the stage for a great deal of the triage system's evolution described below. That approach - in which the Court of Chancery dismisses a stockholder derivative suit unless the complaint alleges specific facts from which it is reasonably conceivable (not just wildly conceivable) that judicial deference in the form of the business judgment rule will not apply - was extended to the not uncommon form of derivative litigation in which the plaintiff claims that the corporation was harmed due to the directors' failure to exercise adequate oversight. We examine that extension, in admittedly truncated fashion, with a review of two key Delaware cases, Caremark ${ }^{115}$ and Stone v. Ritter. ${ }^{116}$

Caremark, a much discussed, ${ }^{117}$ watershed Delaware opinion, did not involve a motion to dismiss (although the court, evaluating a proposed settlement, observed that the plaintiff's derivative claims “quite likely were susceptible to a motion to dismiss.”). ${ }^{118}$ Nevertheless, the opinion was a critical step in establishing the substantive standards governing claims of director liability for alleged oversight failures.

One of the curiosities of the Caremark case is that it began, conventionally enough, as a case asserting director liability for breach of the duty of care, specifically in failing to take steps

${ }^{115}$ In re Caremark Int'l, Inc., 698 A.2d 959 (Del. Ch. 1996).

${ }^{116}$ Note [ ] above.

${ }^{117}$ E.g., Jennifer Arlen, The Story of Allis-Chalmers, Caremark, and Stone: Directors' Evolving Duty to Monitor (2008). New York University Law and Economics Working Papers. Paper 160, available at http://lsr.nellco.org/nyu_lewp/160; Hillary A. Sale, Delaware's Good Faith, 89 Cornell L. ReV. 456, 467 (2004); Matthew R. Berry, Note \& Comment: Does Delaware's Section 102(b)(7) Protect Reckless Directors from Personal Liability? Only if Delaware Courts Act in Good Faith, 79 WASH. L. REV. 1125, 1131 (2004); Mark J. Loewenstein, The Corporate Director's Duty of Oversight, 27 COLO. LAW. 33 (May 1998), available at http://lawweb.colorado.edu/profiles/pubpdfs/loewenstein/98MayTCL-Loewenstein.pdf; Kimberly D. Baker \& Arissa M. Peterson; Post-Caremark Implications for Health Care Organization Boards of Directors, 3 SEATTLE J. SOC. JUST. 387 (2004).

118698 A.2d at 971. 
to avoid exposing the corporation to regulatory sanctions. ${ }^{119}$ Describing it as "possibly the most difficult theory in corporation law upon which a plaintiff might hope to win a judgment,” the court noted the absence of "either director self-dealing or the more difficult loyalty-type problems arising from cases of suspect director motivation, such as entrenchment or sale of control contexts.”120 In essence, the court concluded, as in Trifoods, that claims asserting bad judgments are inherently dismissible, if "there was good faith effort [by the directors] to be informed and exercise judgment.”121

Of course, a key claim in the case did not involve an attack on any director decision; rather, it asserted a failure to become aware of concerns requiring board attention. And in that regard, Chancellor Allen famously concluded that "a director's obligation includes a duty to attempt in good faith to assure that a corporate information and reporting system, which the board concludes is adequate, exists.” ${ }^{22}$ In describing what would be required to establish liability for breach of that duty, however, the court again drew on the concept of good faith, defining the "test of liability" as "lack of good faith as evidenced by sustained or systematic failure of a director to exercise reasonable oversight.”123 Thus, what started out as a claim of breach of the duty of care became

${ }^{119}$ Id. at 960 ("The suit involves claims that the members of Caremark's board of directors (the "Board") breached their fiduciary duty of care to Caremark in connection with alleged violations by Caremark employees of federal and state laws and regulations applicable to health care providers.”).

${ }^{120}$ Id. at 967.

${ }^{121}$ Id. at 968.

${ }^{122}$ Id. at 970.

${ }^{123}$ Id. at 971. 
redefined, in the Chancellor's analysis, as necessarily involving a claim of “lack of good faith.”124

That redefinition in turn shaped the Delaware Supreme Court's opinion in Stone v. Ritter, in which the court did address a motion to dismiss a shareholder derivative complaint, also alleging a board's failure to monitor and prevent regulatory liability. Affirming dismissal of the complaint, the court relied heavily on two aspects of the case: first, the presence of a provision in the company's certificate of incorporation precluding director liability for money damages to the full extent permitted by statute; ${ }^{125}$ and second, the proposition that Court of Chancery Rule 23.1 required dismissal in the absence of "particularized factual allegations” creating a reasonable inference that the directors were subject to personal liability. ${ }^{126}$ And in that regard, the court in Stone fully embraced Caremark's adoption of the principle that director liability for a failure of oversight depended on proof of lack of good faith; indeed, with the following holding, the court completed the metamorphosis of oversight claims from duty of care-based to duty of loyalty-based: "because a showing of bad faith conduct ... is essential to establish director oversight liability, the fiduciary duty violated by that conduct is the duty of loyalty.”"127 Combining these two critical legal premises, the court found little difficulty dismissing the complaint. Indeed, the availability of an outside report assessing the company's relevant

\footnotetext{
${ }^{124}$ It is perhaps curious, therefore, that Chancellor Allen did not directly rely on an exculpatory provision in Caremark's certificate of incorporation based on Section 102(b)(7), note [ ] above. In asserting that a director might be held "liable for losses caused by non-compliance with applicable legal standards," however, he acknowledged that "questions of waiver of liability under certificate provisions authorized by 8 Del.C. § 102(b)(7) may also be faced.” Id. at 970 and n. 27.

${ }^{125}$ Part II.A.3 above describes the nature of this provision and how it came before the court on the motion to dismiss.

${ }^{126}$ Stone, 911 A.2d at 367.

${ }^{127} I d$. at 370 .
} 
compliance efforts and a board-adopted oversight policy enabled the court to conclude that the derivative complaint merely "seeks to equate a bad outcome with bad faith.”128

\section{Krim: Fact Pleading Emerges in Deal Cases}

Thus far we have identified cases in which the Delaware courts have dismissed shareholder derivative suits due to insufficient pleading of specific facts establishing likely director liability. As we will see now, however, the Delaware courts have taken a similar approach to deal litigation. To demonstrate this, we begin with a review of Krim v. ProNet, Inc., a stockholder class action challenge to a merger, and the court's decision on the defendants' motion to dismiss the case for failure to state a claim on which relief could be granted. ${ }^{129}$

We begin with Krim because it involved an arm's length stock for stock merger, and thus was uncomplicated by any issue of enhanced judicial scrutiny under Revlon. ${ }^{130}$ The gravamen of the plaintiff's case was the allegation that the directors of ProNet, the target company, failed to create an active and open auction for ProNet's shares and therefore failed to achieve an appropriate premium recognizing recent upswings in ProNet's business. ${ }^{131}$ In support of these allegations, the complaint cited SEC filings, analysts' reports assessing the value of ProNet’s

${ }^{128}$ Id. at 373. The evolution of oversight liability as based in the duty of loyalty, and the life and death of the concept of the duty of good faith as an element of a "triad" of fiduciary duties, are reviewed more fully in Leo E. Strine, Jr. et al., Loyalty's Core Demand: The Defining Role of Good Faith in Corporate Law, 98 GEO. L. J. 629 (2010).

${ }^{129}$ Krim v. ProNet, Inc., 744 A.2d 523 (Del. Ch. 1999). At an earlier stage of the litigation, the court had denied the plaintiff's motion to expedite discovery. Krim v. ProNet, Inc., C.A. No. 15873 (Del. Ch., Dec. 5, 1997)(bench ruling), tr. at 45-47. We address more fully below the treatment of such motions in deal cases.

130 See text at n.[138] below.

${ }^{131}$ Krim v. ProNet, Inc., Amended Class Action Complaint, Civil Action No. 15873 ("Krim Compl.”) ๆ 45-46. The plaintiff also alleged that the directors breached their fiduciary duties in order to entrench themselves in office. Id. ๆף 47-50. 
shares, and media accounts. ${ }^{132}$ Importantly, the complaint did not allege any failure to disclose any conflict of interest involving the directors or, for that matter, any other material information necessary for a fully informed stockholder vote. ${ }^{133}$

Finding no disabling conflict of interest, ${ }^{134}$ the court could well have viewed the plaintiff's theory as an assertion that he was a better judge of the merger's fairness than the majority of ProNet's fully informed and disinterested stockholders whose approval was

132 The complaint referred to ProNet's low industry leverage ratios, a number of recent lucrative contracts entered into by ProNet, and positive statements by ProNet's CEO and COO in ProNet's 1996 Annual Report to Stockholders. Id. ๆๆ 23-31. Analysts from Principal and Prudential provided values for ProNet's shares on a discounted cash flow basis between \$7 and \$12 per share, which respectively are 30\% and 122\% higher than the merger price of \$5.40 per share. Id. ๆๆ 30-34. Additionally, a Bear Stearns analyst familiar with ProNet valued it at \$8 per share on August 5, 1997, just days before the agreement was announced. Id. ๆ 16.

133 Although the plaintiff's Amended Class Action Complaint did not assert a non-disclosure claim, the plaintiff made a belated assertion of non-disclosure in the plaintiff's Answering Brief to the Defendant's Motion to Dismiss. Krim, 744 A.2d at 528. This non-disclosure claim alleged that the defendant directors failed to confirm or deny that discussions took place with suitors besides MetroCall and failed to provide details if such discussions did occur. Id. The Krim court held that even if such "discussions or negotiations" did exist, they need not be disclosed and that "[the court] can only conclude that what the plaintiff is really trying to do by asserting the disclosure claim is to prolong discovery in the hope of framing a new cause of action." Id. at 528-529. See also Bershad v. Curtiss-Wright Corp., 535 A.2d 840, 847 (Del. 1987) (“[e]fforts by public corporations to arrange mergers are immaterial under the Rosenblatt v. Getty standard, as a matter of law, until the firms have agreed on the price and structure of the transaction.”). 134 The complaint sought to challenge the disinterestedness of ProNet's directors based on matters disclosed in the proxy statement: three of the directors would be named directors of Metrocall after the merger; options held by the board not vested prior to the merger would become fully exercisable and vested on consummation of the merger; and two directors had entered into non-competition agreements in exchange for payments totaling, in the aggregate, $\$ 421,800$ and $\$ 317,400$, over a three-year period. The court found that none of these matters created a conflict of interest. 744 A.2d at [ ] n.16 ("The vesting of options does not create a conflict as a high exchange ratio for ProNet shares benefits the option-holding directors as much as, if not more than, the regular stockholders. Further, the fact that several directors would retain board membership in the merged entity does not, standing alone, create a conflict of interest. See Grobow v. Perot, Del.Ch., 526 A.2d 914, 921-24 (1987) (discussing plaintiff's allegations of directors' interest in "self-perpetuation in office"). 
necessary to accomplishment of the deal. ${ }^{135}$ What made the complaint in Krim particularly easy to dismiss, moreover, was the stock for stock structure of the deal: the business judgment rule protects defendants who make a presumptively informed, disinterested decision in a stock for stock merger, and the more stringent requirements of Revlon do not attach in such a merger because there is no change in control. ${ }^{136}$ Thus, as in Trifoods - Krim's derivative suit counterpart - the court dismissed the complaint because it concluded, at the pleading stage, that "plaintiff has failed to demonstrate any reason why the presumption of the business judgment rule should not be afforded the defendant directors.”137

There is good reason to believe that this pleading stage triage approach does not unduly limit the prosecution of meritorious cases. Mergers and acquisitions, at least those involving publicly traded companies, typically provide all the information required by the trial judge to assess the worthiness of the plaintiff's case. SEC filing requirements reliably elicit extensive, publicly available information about the transaction. A plaintiff who cannot find in that mass of information specific facts calling into question the motivations of the decision makers is most unlikely to be able to succeed at trial in any event. Although, as in Krim, a plaintiff may allege a violation of the duty to disclose by omitting material facts, ${ }^{138}$ the absence of specific allegations of conflict of interest or other improper director motivation appropriately results in dismissal of litigation.

${ }^{135}$ Del. G. Corp. L. § 251(c). See also Williams v. Geier, 671 A.2d 1368, 1381 (Del. 1996) ("[T]he stockholders control their own destiny through informed voting. This is the highest and best form of corporate democracy.”).

${ }^{136}$ Krim, 744 A.2d at 528.

${ }^{137}$ Id. at 527.

138 The plaintiff in Krim alleged that the defendants omitted to disclose material facts about discussions with other potential suitors, but the court dispatched that assertion on the grounds that the plaintiff offered only conclusory allegations about such other discussions or negotiations. Id. at 528. 


\section{Dismissing Non-Revlon Revlon Cases ${ }^{139}$}

It has not always been evident, however, that the motion to dismiss could serve that triage function in deal cases governed by Revlon. ${ }^{140}$ Beginning with its 1986 opinion in that case, the Delaware Supreme Court has made it clear that when the company is sold, ${ }^{141}$ the directors’ conduct must be subjected to enhanced judicial scrutiny, the "key features” of which are “(a) a judicial determination regarding the adequacy of the decisionmaking process employed by the directors, including the information on which the directors based their decision; and (b) a judicial examination of the reasonableness of the directors' action in light of the circumstances then existing. The directors have the burden of proving that they were adequately informed and acted reasonably." 142 Given the requirement of "enhanced scrutiny” in deal cases, and the burden on

${ }^{139}$ We acknowledge Delaware Supreme Court Chief Justice Leo E. Strine, Jr. as the source of this pithy description of this line of cases. The Chief Justice recently admonished students of the subject that "[i]t is too often forgotten that Revlon, and later cases like $Q V C$, primarily involved board resistance to a competing bid after the board had agreed to a change of control, which threatened to impede the emergence of another higher-priced deal.” C\&J Energy Servs., Inc. v. City of Miami Gen. Empl. \& Sanit. Empl. Ret. Trust, 107 A.3d 1049 (Del. 2014). Thus, even though Revlon doctrine applies to any cash sale of the company, a plain vanilla sale, supervised by indisputably independent directors, is clearly far less deserving of judicial scrutiny than the situation faced in Revlon itself. See, e.g., Paul L. Regan, The Unimportance of Being Earnest: Paramount Rewrites the Rules for Enhanced Scrutiny in Corporate Takeovers, 46 HAST. L. J. 125, 126 (1994) (suggesting that the courts should "limit enhanced scrutiny to those instances of director conduct that raise suspicion about the directors' motivations, such as a target board's adoption of defensive measures or unequal treatment of competing bidders.”). Hence, the plain vanilla case can be fairly described as a "non-Revlon Revlon" case.

${ }^{140}$ Revlon, Inc. v. Macandrews \& Forbes, Inc., 506 A.2d 173 (Del. 1986).

141 “Sold," for purposes of Revlon, implies a sale of control or break-up of the company. Paramount Comm's Inc. v. QVC Network, Inc., 637 A.2d 34, 45 (Del. 1993) ("There are few events that have a more significant impact on the stockholders than a sale of control or a corporate breakup. Each event represents a fundamental (and perhaps irrevocable) change in the nature of the corporate enterprise from a practical standpoint. It is the significance of each of these events that justifies: (a) focusing on the directors' obligation to seek the best value reasonably available to the stockholders; and (b) requiring a close scrutiny of board action which could be contrary to the stockholders' interests.”).

142637 A.2d at 47. 
directors to prove that they "acted reasonably," one could have easily concluded that a complaint challenging a transaction involving a sale of control automatically states a claim upon which relief can be granted, and that the complaint therefore cannot be dismissed on motion; rather, the directors must establish (either at trial or at best on a motion for summary judgment) that they “acted reasonably” in approving the transaction. ${ }^{143}$

Indeed, that is essentially what the plaintiffs argued in the critically important case of Malpiede v. Townson, ${ }^{144}$ in which the directors of Frederick's of Hollywood were sued in a challenge to the acquisition of the company for cash. In the Court of Chancery, the plaintiffs advanced the claim, among others, that the directors had breached their duty of care. ${ }^{145}$ Defendants moved to dismiss the complaint for failure to state a claim upon which relief could be granted. According to the plaintiffs in that case, however, dismissal of the duty of care claim was inappropriate and premature, despite the undisputed existence of an exculpatory charter provision relieving the directors of monetary liability for breach of the duty of care. ${ }^{146}$ Specifically, the plaintiffs contended that “Frederick’s exculpatory provision cannot provide the basis to dismiss the complaint at the pleading stage, because the applicability of the charter

${ }^{143}$ A relatively early post-Revlon case demonstrated that defendant directors could win summary judgment in deal cases, but in that case the plaintiffs had taken expedited discovery and the dismissal appears to have been based on an undisputed factual record generated through that discovery effort. Yanow v. Scientific Leasing, Inc., 1991 Del. Ch. LEXIS 134 (Del. Ch. July 31, 1991). More recently, the Delaware Supreme Court directed that summary judgment be entered in favor of the defendant directors in a case challenging the acquisition of Lyondell Chemical Company. Lyondell Chem. Co. v. Ryan, 970 A.2d 235 (Del. 2009). Again, however, the judgment followed discovery and the development of an evidentiary record. One can speculate that competing litigation in Texas might have induced the defendants to go forward with discovery and a motion for summary judgment, rather than present a motion to dismiss that might have been less effective in centering the litigation in the Delaware courts. Id. at _ . 144780 A.2d 1075 (Del. 2001).

${ }^{145}$ In re Frederick's of Hollywood, Inc. S’holders Litig., 2000 Del. Ch. LEXIS 19 (Del. Ch. Jan. 31, 2000).

${ }^{146}$ Id. at 11. 
provision can be determined only on a developed factual record.”147 In this regard, the plaintiffs invoked the Delaware Supreme Court's opinion in Emerald Partners, Inc. v. Berlin, ${ }^{148}$ in which the Court stated that "the shield from liability provided by a certificate of incorporation provision adopted pursuant to 8 Del.C. $\S 102(b)(7)$ is in the nature of an affirmative defense,” and that “[d]efendants seeking exculpation under such a provision will normally bear the burden of establishing each of its elements.”149

Faced with these contentions and the assignment of the burden of proof to the director defendants, the court could easily have agreed with the plaintiffs and insisted that the "enhanced scrutiny” required by Revlon and its progeny could only occur after development and presentation of a factual record, with the directors bearing the burden of proof. In short, the court could have easily determined that a motion to dismiss could not serve a pleading stage triage function in deal cases in which Revlon requires "enhanced scrutiny.”

It was striking, then, that the Court of Chancery reached the opposite conclusion. Having separately concluded that claims of breach of the duty of loyalty were not sufficiently pleaded, ${ }^{150}$ the court held that "where the complaint only alleges a breach of the duty of care, that claim may be dismissed at the pleading stage” based on the exculpatory charter provision. ${ }^{151}$ The Delaware Supreme Court affirmed, stating that "[a]lthough the Revlon doctrine imposes enhanced judicial scrutiny of certain transactions involving a sale of control, it does not eliminate the requirement

\footnotetext{
147 Id. at 20.

148726 A.2d 1215 (Del. 1999).

${ }^{149}$ Id. at $1223-1224$.

${ }^{150}$ Frederick's of Hollywood, Inc., 2000 Del. Ch. LEXIS 19 at 24 ("Id. at _ ("Because the complaint fails to alleged facts that establish that the merger was not approved by a majority of disinterested directors, the breach of loyalty claims cannot survive a motion to dismiss.”).

${ }^{151}$ Id. at 21.
} 
that plaintiffs plead sufficient facts to support the underlying claims for a breach of fiduciary duties in conducting the sale.” ${ }^{152}$ Concluding the point, the Court explained:

[W]e have held that the amended complaint here does not allege a loyalty violation or other violation falling within the exceptions to the Section 102(b)(7) exculpation provision. Likewise, we have held that, even if the plaintiffs had stated a claim for gross negligence, such a well-pleaded claim is unavailing because defendants have brought forth the Section 102(b)(7) charter provision that bars such claims. This is the end of the case. $^{153}$

Thus, as the Delaware Supreme Court much more recently explained, in a case seeking money damages against a director protected by an exculpatory charter provision, a complaint must affirmatively plead non-exculpated claims, regardless of the standard of judicial review that might apply:

A plaintiff seeking only monetary damages must plead non-exculpated claims against a director who is protected by an exculpatory charter provision to survive a motion to dismiss, regardless of the underlying standard of review for the board's conduct-be it Revlon, Unocal, the entire fairness standard, or the business judgment rule. ${ }^{154}$

It would be a mistake to dismiss these rulings as a fortuitous application of exculpatory charter provisions in a limited context, namely in suits limited to damages claims against directors. To the contrary, Malpiede and its progeny ${ }^{155}$ represent a significant extension of fact pleading requirements to deal cases. Exculpatory charter provisions are nearly ubiquitous in

152780 A.2d at 1084 .

${ }^{153}$ Id. at 1094.

${ }^{154}$ Leal v. Meeks (In re Cornerstone Therapeutics, Inc.), , _ A.3d _ , _ [2015 Del. LEXIS 231, *37] (Del. 2015) (in a challenge to a transaction governed by the entire fairness standard of judicial review, remanding "to determine if the plaintiffs have sufficiently pled facts suggesting that the independent directors committed a non-exculpated breach of their fiduciary duty.”).

${ }^{155}$ In re NYMEX Shareholder Litig., (Del. Ch. 2009) (dismissing Revlon-based claims of breach of fiduciary duty in the sale of the company); Wayne County Employees' Ret. Sys.v. Corti, C. A. No. 3534-CC (Del. Ch. July 24, 2009) (same); In re BJ's Wholesale Club, Inc. Shareholders Litigation, 2013 Del. Ch. LEXIS 28 (Jan. 31, 2013) (same). 
publicly traded Delaware corporations, ${ }^{156}$ and once an arm’s length acquisition has been consummated, the only potential defendants in deal litigation are (i) the directors who are protected by such provisions, and (ii) the buyer -- who can typically secure dismissal of the claims against it (aiding and abetting a breach of fiduciary duty) because of the requirement, applied in Malpiede and many other cases, ${ }^{157}$ that the complaint demonstrate "knowing participation” by the buyer in the target directors’ breach of a fiduciary duty. ${ }^{158}$

In short, deal cases challenging arm's length acquisitions can be dismissed at the pleading stage, despite the application of Revlon "enhanced scrutiny.”

\section{Dismissing Deal Cases Involving Controlling Stockholders}

In the previous section we examined the extension of fact pleading requirements to motions to dismiss deal cases in which the acquisition is by an unaffiliated third party, and there are no viable claims of conflict of interest or otherwise disloyal motivation. As we saw, that extension depended significantly on the application of exculpatory charter provisions that eliminate monetary liability on claims not involving disloyalty or other narrow exceptions. Such provisions would of course not protect controlling stockholders, or directors affiliated with them,

${ }^{156}$ Andrew C. W. Lund, Rethinking Aronson: Board Authority and Overdelegation, 11 U. PA. J. Bus. L. 703, 704 (2013) (exculpatory charter provisions "have been adopted by the vast majority of Delaware corporations”); Claire A. Hill \& Brett H. McDonnell, Disney, Good Faith, and Structural Bias, 32 J. CoRP. L. 833, 837 (2007) ("personal liability for pure care violations” has been waived by most corporations); Robert B. Thompson \& Randall S. Thomas, The Public and Private Faces of Derivative Suits, 57 VAND. L. REV. 1747, 1786 (2004) ("It is very rare for a public company not to have taken advantage of this exculpation.”).

${ }^{157}$ E.g., Gotham Partners, L.P. v. Hallwood Realty Partners, L.P., 817 A.2d 160, 172 (Del. 2002) (holding that elements of a claim for aiding and abetting a defendant include establishing that a defendant "who is not a fiduciary, knowingly participated in a breach; In re Nine Sys. Corp. S'holders Litig., 2014 Del. Ch. LEXIS 171, *146 (Del. Ch. Sept. 4, 2014) ("Under Delaware law, to recover on a claim for aiding and abetting another's breach of fiduciary duty, a plaintiff must prove ... knowing participation in the breach by the non-fiduciary defendants'”); In re Rural Metro Corp. Stockholders Litig., 88 A.3d 54, 80 (Del. Ch. 2014) (accord).

${ }^{158}$ Malpiede, 780 A.2d at 1096. 
in cases in which the controller is the acquiring party. In a number of situations, however, the courts have employed the motion to dismiss as a triage tool even in cases in which the merger is supported by an allegedly controlling stockholder. We identify and examine three such situations below: (1) claims against disinterested directors in a controller freeze-out transaction; (2) claims against directors and controlling stockholders where both the controller's shares and the publicly held shares are sold to an unaffiliated third party; and, most controversially, (3) claims against the directors and controller, where the controller has irrevocably conditioned the freeze-out acquisition upon approval by both a special committee of disinterested directors and a majority of the outstanding minority shares. In each of these situations, the Delaware courts have come to require pleading of facts sufficient, on a motion to dismiss, to rebut the application of an exculpatory charter provision or the business judgment rule.

\section{i. $\quad$ Claims Against Disinterested Directors}

Until this year, it was unclear as a matter of Delaware law whether, in a freeze-out merger by a controlling stockholder, unaffiliated directors could be dismissed as defendants in the absence of pleaded facts establishing a non-exculpated claim against them. ${ }^{159}$ The Court of Chancery, aware of the uncertainty on this point but guided by statements in the Delaware Supreme Court's opinion in Emerald Partners, declined to grant such dismissals, given that the underlying transaction would be subject to review under the demanding standard of entire fairness. ${ }^{160}$ The Delaware Supreme Court accepted interlocutory appeals from those denials in

${ }^{159}$ In re Cornerstone Therapeutics Inc. Stockholder Litig., 2014 Del. Ch. LEXIS 170, *19 (Del. Ch. Sept. 10, 2014), rev'd, Leal v. Meeks, _ A.3d _ (Del. 2015) (noting “[t]he lack of congruity in our case law with respect to transactions subject to entire fairness”).

${ }^{160}$ Cornerstone, 2014 Del. Ch. LEXIS at *41 (Del. Ch. Sept. 10, 2014) (“controlling precedent requires me to deny the Motion to Dismiss under these circumstances."); In re Zhongpin Inc. Stockholders Litig., 2014 Del. Ch. LEXIS 252, *36 (Del. Ch. Nov. 26, 2014) (“Although In re 
order to clear up that uncertainty. ${ }^{161}$ In Leal v. Meeks, the court established that disinterested directors were entitled to dismissal, even in a case challenging a controller freeze-out transaction, in which the most searching form of judicial review would apply to the transaction, unless nonexculpated claims were specifically pleaded against those directors. ${ }^{162}$

That holding is instructive, but does not advance the larger thesis advocated here. On one hand, it is instructive because it identifies yet another arena in which the Delaware courts have manifested a willingness to dismiss claims because of a failure to plead specific facts sufficient to imply a basis for liability. And that willingness flows logically from the courts' earlier rulings in arm's length deal cases, particularly Malpiede, which pointedly distinguish the applicable standard of judicial review from the governing pleading standard, and establish that nonexculpated claims must be pleaded with specificity even if Revlon ultimately calls for enhanced judicial scrutiny. Indeed, it is no accident that the court in Cornerstone repeatedly relies on and quotes the court's earlier opinion in Malpiede. ${ }^{163}$ On the other hand, pointing out the willingness to dismiss individual disinterested directors in a controller freeze-out case is something of a

Cornerstone questioned the merit of forcing disinterested directors to face the same pleading standard as interested fiduciaries in cases subject to entire fairness, the Court's examination of precedent left it with no other choice.”).

${ }^{161}$ In both Cornerstone and Zhongpin the Court of Chancery granted, and the Delaware Supreme Court accepted, defendants' requests that the denial of their motion to dismiss be taken up in an interlocutory appeal. Leal v. Meeks, _ A.3d at _ [2015 Del. LEXIS 231*13-14] ("These cases ... exemplify a benefit of careful employment of the interlocutory appeal process: to enable this Court to clarify precedent that could arguably be read in two different ways before litigants incur avoidable costs”);; In re Cornerstone Therapeutics Inc. S'holders Litig., 2014 Del. Ch. LEXIS 185, (Del. Ch. Sept. 26, 2014); In re Cornerstone Therapeutics Inc. S'holders Litig., No. 564, 2014 (Del. Oct. 9, 2014) (ORDER); In re Zhongpin Inc. Stockholders Litig., 2014 Del. Ch. LEXIS 267 (Del. Ch. Dec. 23, 2014).

162 Leal,_A.3d at _[2015 Del. LEXIS 231, *35] ("when the plaintiffs have pled no facts to support an inference that any of the independent directors breached their duty of loyalty, fidelity to the purpose of Section 102(b)(7) requires dismissal of the complaint against those directors.”). ${ }^{163}$ Id. at nn. 4, 12, 26-27, and 33-34. 
digression from the main thesis of this Article: dismissing disinterested directors while allowing the case to go forward against the controller and its affiliated directors does little or nothing to avoid the costs of litigation, which would generally continue despite dismissal of the disinterested directors; nor can that dismissal be expected to assist the parties to predict the ultimate disposition of the litigation, because the claims against the controller would be governed by fairness considerations independent of those on which liability of the disinterested directors would have to be premised. ${ }^{164}$ Accordingly, this particular application of the motion to dismiss does not significantly exemplify the previously described efficiency functions of the motion to dismiss. The other two areas identified below, however, are more relevant to the efficiency thesis we advance.

\section{ii. $\quad$ Sales by a Controller to a Third Party}

In some situations, the controlling stockholder becomes a seller. Where that occurs and the company is sold to a third party in an arm's length transaction in which the controller receives the same consideration per share as the minority stockholders, one would ordinarily expect that judicial review of the sale would be at least as favorable to the proponents of the transaction as in an ordinary arm’s length acquisition: the controller has a powerful incentive to achieve exactly what Revlon calls for, namely the highest currently available sale price.

The Delaware Supreme Court's 2000 opinion in McMullin v. Beran, ${ }^{165}$ however, called into question the viability of a motion to dismiss as a triage tool in cases in which a controlling stockholder is a seller, along with the minority stockholders. In that case, the court reversed the ${ }^{164}$ Leal, _ A.3d at [ ]_ n. 40 ("Interested fiduciaries, often the proverbial deep-pocketed defendants, will continue to be required to prove that the transaction was entirely fair to the minority stockholders, because the plaintiffs ' well-pled claims against the interested parties in a controller transaction cannot be dismissed before trial, regardless of whether the independent directors remain as defendants.”).

${ }^{165}$ McMullin v. Beran, 765 A.2d 910 (Del. 2000). 
grant of a motion to dismiss that emphasized the alignment of economic interest between the controller (ARCO) and the minority in a sale of the company (Chemical) to a third party (Lyondell). The court rejected dismissal in part because of its conclusion that the complaint's allegations "suggest that the directors of Chemical breached their duty of care by approving the merger ... without adequately informing themselves about the transaction and without determining whether the merger consideration equaled or exceeded Chemical's appraisal value as a going concern.” ${ }^{166}$ In this case decided shortly before Malpiede, the court oddly declined to consider the impact of the company’s exculpatory charter provision ${ }^{167}$ - oddly, because under the subsequent reasoning of Malpiede that provision would have provided an independent basis for affirming the lower court's dismissal of the complaint, at least as against the directors. More importantly, the court found the allegations of the complaint sufficient to implicate a conflict of interest on the part of the controller, despite the equal treatment of all shares in the merger: the controller was allegedly in need of cash, and "its insistence on an all-cash bid conflicted with the interests of the public shareholders to receive maximum consideration for their shares in a sale of the Company. ${ }^{168}$ If a controller's ostensible preference for (or against) liquidity were automatically a basis for finding a conflict of interest and therefore a viable claim for breach of the duty of loyalty, dismissal of a challenge to even an arm's length sale would seem to be difficult or impossible.

McMullin was not the last word, however, on cases of this sort: twelve years later, then Chancellor Strine addressed a similar complaint challenging a sale to a third party, where the

\footnotetext{
${ }^{166} I d$. at 922.

${ }^{167}$ Id. at 926.

${ }^{168}$ Id. at 921.
} 
controller received the same per share consideration as the public stockholders. ${ }^{169}$ In that case (Synthes), the court did grant defendants' motion to dismiss a complaint challenging the sale. The opinion nicely illustrates elements of the procedural system we describe above, including the courts' evolving insistence in representative shareholder litigation that the complaint demonstrate with reasonable specificity a basis for further judicial inquiry into the merits of the claims.

The operative complaint in Synthes was a second amended complaint, and the plaintiffs had been "afforded some written discovery." 170 Perhaps more importantly, the plaintiffs had received, and drew heavily in their complaint from, the defendants’ proxy statement; and plaintiffs' reliance on that document in pleading their claims enabled the court to rely on the facts it recited, in the absence of specifically pleaded facts contradicting those recitations. ${ }^{171}$

As in McMullin, the plaintiffs alleged that the putative controller (Wyss) had a "unique" need for liquidity that "infected the entire sale process." "172 Rather than infer a conflict of interest arising from that alleged liquidity preference, however, the court's analysis proceeded from the premise that "a fiduciary's financial interest in a transaction as a stockholder (such as receiving liquidity value for her shares) does not establish a disabling conflict of interest when the

${ }^{169}$ In re Synthes, Inc. S'holder Litig., 50 A.3d 1022 (Del. Ch. 2012).

17050 A.3d at 1024. In a similar case, discovery appears to have been considerably further advanced. In re Morton's Restaurant Group, Inc., 74 A.3d 656, 658 (Del. Ch. 2013) ("the plaintiffs have received substantial discovery, including depositions”). Although the court granted a motion to dismiss, as it did in Synthes, the court's reliance on deposition testimony as well as SEC filings deemed to have been incorporated into the complaint (id. at 658-659) resulted in a disposition that may have resembled summary judgment more than a motion to dismiss.

${ }^{171} \mathrm{Id}$. at 1026 ("Having premised their recitation of the facts squarely on that document and incorporated it, the plaintiffs cannot fairly, even at the pleading stage, try to have the court draw inferences in their favor that contradict that document, unless they plead non-conclusory facts contradicting it.”), citing In re BHC Commc'ns S'holder Litig., Inc., 789 A.2d 1, 13 (Del. Ch. 2001).

${ }^{172}$ Id. 
transaction treats all stockholders equally."173 The court allowed that there might be "very narrow circumstances in which a controlling stockholder's immediate need for liquidity could constitute a disabling conflict of interest irrespective of pro rata treatment," ${ }^{174}$ but it insisted on and found no - specific allegations that such narrow circumstances (like an exigent need for cash to meet a margin call) existed. To the contrary, the court found that the undisputed facts about the sale process - its relatively deliberate pace, and its effort to reach both strategic and private equity buyers - contradicted any claim that any unique liquidity preference on the part of the controller motivated the sale. ${ }^{175}$

The court also rejected a challenge to the deal protections in the transaction, including "a 3.05\% termination fee; a no-solicitation provision with a fiduciary out; matching rights; a "forcethe-vote" provision; and the Voting Agreement locking up 37\% (or 33\% upon a change in the Board's recommendation) of Wyss' and his affiliates' shares in favor of the Merger."176 The court reasoned that the plaintiffs had "made no attempt to show how the deal protections would have unreasonably precluded the emergence of a genuine topping bidder willing to make a materially higher bid, and thus fail to state a claim. ${ }^{177}$ In the same vein, the court concluded that the board's approval of the deal protections was the "sort of tactical judgment [that] is freighted with none of the concerns about disloyalty that animate Unocal and Revlon, and is one that courts are illequipped to second guess as unreasonable.”178

\footnotetext{
${ }^{173}$ Id. at 1035.

${ }^{174}$ Id. at 1036.

${ }^{175}$ Id. at 1037.

${ }^{176}$ Id. at 1048 n. 118.

${ }^{177}$ Id.

${ }^{178}$ Id. at 1049.
} 
In sum, Synthes is a classic illustration of the Delaware courts' evolved approach to dismissal motions: using a liberal but fair identification of the universe of relevant facts (especially where the plaintiffs had relied on the defendants' proxy statement), the court engaged in a factually nuanced assessment of claims of disloyal motive and, finding the alleged facts an insufficient basis from which to infer such disloyalty, dismissed the complaint. ${ }^{179}$ That sort of robust factual analysis would undoubtedly unsettle those accustomed to liberal notice pleading concepts; but it demonstrates a salutary recognition that undue fealty to those concepts imposes substantial costs on investors.

iii. Controller Freeze-Outs Conditioned on Special Committee and Minority Stockholder Approval

In contrast to the sale addressed in Synthes, transactions in which the controlling stockholder is acquiring the minority's shares - and where the economic interests of the

179 The court in Synthes did not, on the other hand, deeply inquire into whether Wyss was indeed a controlling stockholder for purposes of legal analysis: his ownership of 38\% of the shares, plus "his control of $13.25 \%$ of the company's shares owned by family members and trusts," was evidently enough to persuade the court that further inquiry into Wyss' control was unnecessary. Id. at 1025 . Where the putative controller owns less than an absolute majority of the voting shares, however, the Delaware courts engage in a robust analysis of pleaded facts to evaluate whether actual control has been exercised. See In re Crimson Exploration, Inc. Stockholder Litigation, 2014 Del. Ch. LEXIS 213, *32-*33 (collecting Delaware cases examining controller status). In Crimson, the court expressed considerable doubt that the alleged controller in fact exercised the required actual control - an expression of doubt that would surely have guided the parties in considering settlement had the case not been dismissed for other reasons - but noted that plaintiffs "only need to show it is reasonably conceivable that Oaktree controlled Crimson." $I d$. at *56. The court then grudgingly stated: "I am hesitant to conclude that Plaintiffs could not conceivably make that showing.” Id. Subsequently, however, the court in In re KKR Fin. Holdings LLC Shareholder Litigation, 101 A.3d 980 (Del. Ch. 2014) dismissed a merger challenge based on the proposition that KKR was a controller of KKR Financial Holdings ("KJN"), finding that "there are no well-pled facts from which it is reasonable to infer that KKR could prevent the KFN board from freely exercising its independent judgment in considering the proposed merger.” Id. at 996. 
controller and the minority are thus antithetical - are tested by standards of “entire fairness,”180 and motions to dismiss complaints challenging such transactions are understandably close to non-existent. ${ }^{181}$ The Delaware courts have come to recognize, however, that the prospect of avoiding litigation could supply a useful incentive to employ deal techniques that provide protection to minority stockholders that is substantially equivalent to arm's length bargaining. ${ }^{182}$ That recognition was most clearly articulated by the Court of Chancery only fairly recently, when it granted summary judgment to a defendant controller which had from the inception of the transaction conditioned its acquisition of the minority shares upon approval by an appropriately empowered special committee of disinterested, independent directors and the favorable uncoerced, fully informed vote of a majority of the minority stockholders. ${ }^{183}$ In that case, the court reasoned that with this approach, “an across-the-board incentive would be created to provide minority stockholders with the best procedural protections in all going private transactions. Whether proceeding by a merger or a tender offer, a controlling stockholder would recognize that it would face entire fairness review unless it agreed not to proceed without the

${ }^{180}$ E.g., Weinberger v. UOP, Inc., 457 A.2d 701, 99 (Del. 1983) ("The requirement of fairness is unflinching in its demand that where one stands on both sides of a transaction, he has the burden of establishing its entire fairness, sufficient to pass the test of careful scrutiny by the courts.”).

${ }^{181}$ As the Delaware Supreme Court recently explained, when the complaint alleges facts sufficient to implicate the entire fairness standard "at the pleading stage, the plaintiffs will be able to survive a motion to dismiss by interested parties regardless of the presence of an exculpatory charter provision because their conflicts of interest support a pleading-stage inference of disloyalty.” Leal v. Meeks, _ A.3d at _.

182 This idea emerged most famously in Weinberger v. UOP, Inc., 457 A.2d _ (Del. 1983), where the Delaware Supreme Court suggested that the result in the case might have favored the defendants had the directors established a special committee of disinterested, independent directors to negotiate the terms of the merger with the controlling stockholder.

${ }^{183}$ In re MFW S'holders Litig., 67 A.3d 496 (Del. Ch. 2013), aff'd, Kahn v. M\&F Worldwide Corp., 88 A.3d 635 (Del. 2014). 
approval of an independent negotiator with the power to say no, and without the uncoerced, fully informed consent of a majority of the minority." 184

In that case, however, the court entered judgment for the defendants only after extended discovery, and on a motion for summary judgment; left open was the question of whether use of the two-part procedure outlined by the court would provide a basis for a motion to dismiss for failure to state a claim. On appeal, that question was addressed, in dictum, in a footnote, and in a way that cast doubt on the utility of the two-step procedure as a basis for dismissal at the pleading stage: specifically, the Delaware Supreme Court's opinion indicated that the complaint in the case would have withstood a motion to dismiss, largely because of allegations that the merger price was inadequate. ${ }^{185}$ Of course, if allegations of price inadequacy will be sufficient to prevent dismissal, the litigation-avoidance incentive identified by the Court of Chancery would likely be substantially weakened, if not rendered trivial.

There have been indications, however, that the motion to dismiss may yet have some vitality as an incentive for controlling stockholders to use the two-step procedure in freeze-outs. First, two recent rulings in the Court of Chancery suggest a willingness to dismiss on that basis. In one of those cases, the court granted a motion to dismiss, noting that "the whole point of encouraging this structure was to create a situation where defendants could effectively structure a transaction so that they could obtain a pleading-stage dismissal against breach of fiduciary duty claims.”186 The court felt that when the elements of the two-step process are established, the complaint can avoid dismissal only where "the plaintiffs have pled facts sufficient to call into

\footnotetext{
18467 A.3d at 504.
}

18588 A.3d at 645 n. 14.

${ }^{186}$ Swomley v. Schlecht, C.A. No. 9355-VCL (Del. Ch. Aug. 27, 2014) (Transcript Ruling at 6677). 
question the existence of those elements, at least when those elements have been described in a

public way suitable for judicial notice, such as board resolutions and a proxy statement ... .»187 In another case, albeit in dictum, the Court of Chancery indicated that "a motion to dismiss may be granted where the transaction is conditioned ab initio on a majority-of-the-minority vote and is negotiated by a facially disinterested and independent special committee.”188

The second, and perhaps more forceful, basis for believing that the Delaware Supreme Court will support pleading stage dismissal based on use of the two-step process - apart from the forceful logic that such dismissal will encourage controllers to use a process that protects minority stockholders - is the thrust of the court's subsequent opinion in Leal v. Meeks. As noted above, that opinion embraces the idea that the independence and care of directors serving on a special committee is to be presumed, and if the efficacy of the committee approval process is to be questioned on the ground that its members failed to act with care and independence, the complaint must set forth some specific facts on which such questioning can be based.

\section{The Evolution and Importance of the Motion to Expedite Discovery}

We have now observed how the Delaware courts have expanded the role of the motion to dismiss in representative shareholder litigation. As previously noted, however, the motion to dismiss, although certainly less time-consuming than trial, cannot ordinarily be presented and resolved in the fairly short time in which the typical corporate acquisition occurs. And if a shareholder plaintiff brings a class action seeking to enjoin the consummation of such an acquisition, the court can scarcely call a transactional "time out" while it is deciding a motion to dismiss, on the theory that doing so could efficiently eliminate further litigation expense or

\footnotetext{
${ }^{187}$ Id., 69-70.

${ }^{188}$ In re Cornerstone Therapeutics Inc. Stockholder Litig., 2014 Del. Ch. LEXIS 170, *37-38 (Del. Ch. Sept. 10, 2014), rev'd on other grounds,_A.3d _(Del. 2015).
} 
promote an informed settlement. Instead, the court is typically called upon to schedule a hearing on a motion for a preliminary injunction against the transaction, and, in that connection, to authorize the plaintiff to accelerate the discovery time frame prescribed in the rules of civil procedure.

Not too long ago, such a motion to expedite discovery might have been routinely granted, where the plaintiff sought to enjoin a pending merger. As Chancellor Allen explained in such a case, “[t]he presence of a transaction of some sort, a shareholders meeting, the closing of a tender offer or the closing of some structural transaction (a recapitalization, sale of substantial assets, etc.), is typically the reason in such cases to permit expedited discovery." 189 If the pendency of a merger transaction were routinely sufficient to justify expedited discovery, however, the efficiency of the motion to dismiss in deal cases would largely be eliminated: a plaintiff could simply seek to enjoin a pending deal and, on the barest and most conclusory of allegations of misconduct, set into motion a hugely expensive discovery process in the hope that it would drive defendants to offer a (cosmetic?) settlement and a fee award.

Perhaps that scenario could never have played out in the Delaware courts, despite the liberality of granting motions to expedite discovery in deal cases. ${ }^{190}$ But with typical insight and prescience, Chancellor Allen, in a 1994 ruling, recognized and articulated the concern that efficiency considerations required that, at least to some degree, a motion to expedite discovery had to clear some substantive hurdle involving an evaluation of the merits of the case. In

${ }^{189}$ Am. Stores Co. v. Lucky Stores, Inc., 1988 Del. Ch. LEXIS 182, *4 (Del. Ch. Apr. 13, 1988). See also Kurt Heyman, Expedited Proceedings in the Delaware Court of Chancery: Things of the Past?, 23 DEL. J. CORP. L. 145, 146 (1998) ("applications for expedited proceedings ..., prior to this decade, were granted almost routinely and occasionally on an ex parte basis.”).

${ }^{190}$ Heyman, supra note [ ], at *149-*156 (reviewing pre-1994 cases in which the Court of Chancery denied a motion to expedite discovery notwithstanding the pendency of a transaction). 
Giammargo v. Snapple Beverage Corp., ${ }^{191}$ Chancellor Allen denied a motion to expedite discovery in a case seeking to enjoin the sale of Snapple to Quaker Oats. In a memorable analysis, Chancellor Allen explained his ruling as follows:

The court is not required or able on this application to judge the merits or even the legal sufficiency of these pleadings. The question presented is a more specialized one: whether in the circumstances the plaintiff has articulated a sufficiently colorable claim and shown a sufficient possibility of a threatened irreparable injury, as would justify imposing on the defendants and the public the extra (and sometimes substantial) costs of an expedited preliminary injunction proceeding. This court traditionally has acted with a certain solicitude for plaintiffs in this procedural setting and thus has followed the practice of erring on the side of more hearings rather than fewer. We continue that tradition of solicitude. But our responsibility to all parties and to the public's interest in efficient justice requires, nevertheless, that where there clearly is no demonstrable need for the remedy of preliminary injunction or, in the rarer case when there is not even any colorable claim pleaded, that we decline to impose the costs associated with such a proceeding. ${ }^{192}$

With that ruling it became clear that the court could - indeed, was obliged to - evaluate the merits of the claims presented before granting a motion to expedite discovery. ${ }^{193}$ That evaluation is necessarily limited - the issue is merely whether the claims presented are "sufficiently colorable" - but just as has occurred with the motion to dismiss, the court engages in substantive triage. Indeed, no other approach would make sense, given the possibility that the

1911994 Del. Ch. LEXIS 199 (Del. Ch. Nov. 15, 1994).

${ }^{192}$ Id. at *5-*6.

${ }^{193}$ It is not clear under the Federal Rules of Civil Procedure that the court inquires into the substantive merits in deciding motions to expedite discovery. In one approach, the court considers the same factors as apply in deciding a motion for preliminary injunction, including whether there is "some probability of success on the merits." 6-26 Moore's Federal Practice Civil § 26.121[2]. The more liberal "reasonableness" test, however, does not explicitly call for examination of the merits of the underlying claims being asserted. Id. ("Among the factors to be considered by the court are: (1) whether a preliminary injunction motion is pending; or another legally cognizable urgency exists, (2) the breadth of the discovery requests; (3) the purpose for requesting the expedited discovery; (4) the burden on the defendants to comply with the requests; and (5) how far in advance of the typical discovery process the request was made.”). 
defendants and the public would have to bear "the extra (and sometimes substantial) costs of an expedited preliminary injunction proceeding” despite the absence of any meritorious claim.

The obvious question, then, is whether and to what extent the substantive inquiry on a motion to expedite differs from the substantive inquiry on a motion to dismiss. Can a complaint be "sufficiently colorable” to warrant expedited discovery yet not articulate "reasonably conceivable” claims sufficient to resist a motion to dismiss? One would expect that if a court finds that a complaint is not sufficiently "colorable” to support granting a motion to expedite discovery, it is unlikely that it would set forth "reasonably conceivable” claims sufficient to overcome a motion to dismiss. ${ }^{194}$ But should the two standards be significantly different? In both situations, the plaintiff ordinarily has not had the benefit of discovery.

We perceive only two differences between the two procedural contexts. First, a motion to dismiss is ordinarily a more deliberate affair, usually affording sufficient time to permit the gathering of facts through means (such as exercise of inspection rights) not involving discovery; the time frame of a motion to expedite discovery, in contrast, may not permit that more leisurely gathering of information. Second, in deal cases, at least, the application for preliminary injunctive relief is not precluded by any exculpatory charter provision, as a post-closing damages case may be. For these two reasons, courts might appropriately be more likely to find “colorable” claims on a motion to expedite, while demanding more cogent showings of "reasonably conceivable” claims on a motion to dismiss.

Again, though, and regardless of minute differences in the standard of substantive review, it is important to appreciate that in both procedural contexts the Delaware courts are engaging in

194 See In re Bioclinica, Inc. S'holder Litig., 2013 Del. Ch. LEXIS 250, n. 46 (Del. Ch. Oct. 16, 2013) ("The standard for a motion to expedite is 'colorability' and the standard for a motion to dismiss under Rule 12(b)(6) is 'reasonable conceivability' —in my view, a higher, although still minimal, pleading burden.”). 
a substantive evaluation of the merits of the underlying claims. Thus, just as the Delaware courts have demonstrated a willingness to dismiss even cases governed by the Revlon standard of “enhanced scrutiny,” they have also sometimes declined to set the discovery process in motion on an expedited basis even when a shareholder plaintiff seeks a preliminary injunction in such a case. In its 2013 opinion In re Bioclinica, Inc., ${ }^{195}$ for example, the Court of Chancery denied a motion to expedite discovery in connection with a complaint seeking to preliminarily enjoin a merger in which the company would be acquired on a cash for stock basis (thus implicating enhanced judicial scrutiny). As might be expected in a case asserting a Revlon-based claim, the complaint alleged that the merger agreement and related arrangements included a "combination of devices - a no-shop clause, a top-up feature, matching rights, a termination fee, a poison pill, and a standstill agreement — [ that were] preclusive to other potential bidders.” ${ }^{196}$ Nevertheless, after an extended analysis rejecting a claim that the company’s shareholder rights plan would effectively preclude competing bids that would enable the board to exercise a fiduciary out in the merger agreement, the court concluded that the deal protection devices at issue were conventional, and that "the Plaintiffs have not pled a colorable claim that these deal-protection devices, when combined, impermissibly lock up the Merger Agreement.”197

\section{Cases Denying Motions to Dismiss, and the Promotion of Efficient Settlements}

Thus far we have examined Delaware's triage system for representative shareholder litigation with a somewhat one-sided view of efficiency: specifically, we have focused on cases in which the grant of a motion to dismiss, or denial of a motion to expedite discovery, either ends the litigation or at least defers and perhaps avoids costly discovery. These are the cases which in

\footnotetext{
1952013 Del. Ch. LEXIS 52 (Del. Ch. Feb. 25, 2013).

196 Id. at $* 7$.

${ }^{197}$ Id. at *16-*17.
} 
which the court preliminarily finds that they lack substantive merit. But what about the converse situation, where the motion to dismiss is denied, or expedited discovery is permitted, because the court finds the claims presented to be either "reasonably conceivable" or "substantially colorable?”

We claim that even in this converse situation, the system has promoted efficiency by enhancing the opportunity for inexpensive disposition of the litigation through voluntary settlement. To be sure, not every denial of a motion to dismiss so accurately predicts the outcome of trial that settlement inevitably ensues. Like unhappy families, each lawsuit that fails to settle is unhappy in its own way: ${ }^{198}$ opposing parties can have irreconcilably heterogeneous expectations about what the facts will ultimately establish at trial, about how witness credibility will be assessed, or about how the court will ultimately apply legal principles to the facts presented; and the factual "record" on a motion to dismiss (or to expedite discovery) is necessarily incomplete, to some degree, relative to the record that would be presented at trial. Settlement may be deterred by the fact that parties have different appetites for risk, or for current versus future expenditures. And, parties are not always perfectly rational (quite an understatement, to anyone who has ever been a lawyer more than briefly). So there are many reasons why any given case might not settle, even after the denial of a motion to dismiss provides the clearest of articulations of the court's preliminary assessment of the facts and the law, and even where the court is able to consider a substantial body of undisputed facts.

Our claim, however, is that preliminary assessments of the merits in Delaware's triage system can facilitate settlement, even if they do not invariably result in settlement. We review examples of this result below, but the reasons to believe that such efficiencies exist derive from

${ }^{198}$ LEO TOLSTOY, ANNA KARENINA (1877) ("Happy families are all alike; every unhappy family is unhappy in its own way.”). 
the assessment of the Delaware system described above. We posit first that rational clients and their counsel, given reasonably clear legal principles and a shared understanding of the relevant facts, will prefer to settle, on a basis that they predict would emerge after trial, rather than incur the substantial costs of going through with a trial. And because Delaware's triage system in representative shareholder litigation provides (1) a substantive assessment of the merits of the claims, that is (2) presented by the same judge who will hear and decide the case after trial, (3) based on a substantial body of relevant and essentially undisputed facts, that system enables the parties to make a much more informed prediction about the likely outcome after trial, which contributes to making the parties' expectations in that regard much more congruent than in a system with a less searching preliminary inquiry into the merits on a motion to dismiss.

Recent litigation involving a challenge to a “dead hand proxy put” approved by the board of directors of Healthways illustrates the settlement-promoting role of the motion to dismiss. In that case, ${ }^{199}$ a shareholder of Healthways, Inc. sought to invalidate an agreement, entered into after a threatened proxy context emerged, that the company's principal creditor would be entitled to accelerate the company's debt obligations if in the prior two years directors elected by dissident stockholders came to comprise a majority of the board. Suing both on behalf of a class of Healthways stockholders and, in the alternative, derivatively on behalf of the company, the plaintiff named both the directors of the company and the lender as defendants, the latter on the theory that it aided and abetted the directors' breach of fiduciary duty. All defendants moved to dismiss, with the lender defendant asserting that the complaint failed to state a claim against it, and the directors asserting that the plaintiff's claims were not ripe for adjudication. Plaintiff had sought and obtained, pursuant to statutory inspection rights, documents relating to the adoption

199 Pontiac Gen. Emps. Ret. Sys. v. Ballantine, et al., C.A. No. 9789-VCL (Del. Ch. Oct. 14, 2014) (transcript ruling). 
of the proxy put, none of which reflected any "substantive negotiation" about the provision or any “extraordinarily valuable economic benefits” received by Healthways on accounting of granting the put. ${ }^{200}$

In a ruling from the bench, the court denied the motion to dismiss. ${ }^{201}$ In addressing the viability of the aiding and abetting claim, the court rejected the lender's assertion that its arm's length status insulated it from liability: prior rulings on proxy puts, said the court, "should have put people on notice that there was a potential problem here such that the inclusion of the provision was, for pleading-stage purposes, knowing.”202 That ruling, if nothing else, alerted the lender that its ability to enforce the loan agreement, with the proxy put, was no longer secure. And indeed, on February 11, 2015 - less than four months after the denial of the motion to dismiss - the parties filed a stipulation of settlement providing for the cancellation of the proxy put. The settlement was approved on May 8, 2015. ${ }^{203}$ In sum, after having used its statutory inspection rights to establish the absence of any negotiated benefit from the proxy put, the plaintiff was able to survive a motion to dismiss its complaint which, in turn, led to a nearly immediate settlement in which the plaintiff obtained essentially the relief that it would have sought at trial. And according to the court's docket in the case, all of this occurred without a single formal discovery request.

The motion to expedite discovery can serve the same sort of function as the motion to dismiss. We begin with a case where the motion was granted. In Police \& Fire Ret. Sys. v.

${ }^{200}$ Id. at 71.

${ }^{201}$ Id. at 68-81.

${ }^{202}$ Id. at 81.

203 Pontiac Gen. Emps. Ret. Sys. v. Ballantine, et al., C.A. No. 9789-VCL (Del. Ch. May 8, 2015) (transcript ruling). 
Bernal, ${ }^{204}$ the plaintiff sought expedited discovery in aid of a motion for a preliminary injunction against a merger with an arm's length acquirer. In some respects the deal protections in the merger agreement seemed conventional - a matching right, a no-shop agreement, and a termination fee - and defendants opposed expedition, arguing that such deal protections did not give rise to a colorable claim. The court rejected defendants' argument, however, and while its expedited opinion does not analyze the merits extensively, it does recite some facts that could explain why refined judicial antennas might have picked up a signal of breach of duty: the merger agreement, including its deal protections, was entered into after a competing bidder had expressed interest and a meeting with that potential bidder had been scheduled, but before the meeting took place. ${ }^{205}$ The potential bidder then outbid the merger partner by $\$ 5$ per share, and after the partner exercised its match right, the target insisted that it was precluded from negotiating further with the competing bidder. In short, the court could well have concluded (and evidently did) that this was a case where the deal protections prematurely stifled the bidding.

In any event, less than two weeks after the court granted the motion to expedite discovery, the competing bidder raised its offer by another $\$ 3.50$ per share, and two days later the target entered into a merger agreement with the competing bidder, with none of the challenged deal protections ${ }^{206}$ - doing exactly what it had previously told the court it was precluded from doing. Evidently, in the face of the court's ruling on the motion for expedited discovery, neither the target nor the original merger partner felt confident that the no-shop

2042009 Del. Ch. LEXIS 111 (Del. Ch. June 26, 2009).

${ }^{205}$ Id. at $1-3$.

${ }^{206}$ Pontiac Police \& Fire Ret. Sys. v. Bernal, C.A. No. , 4663-CC, Stipulation of Settlement and Dismissal, entered on Jan. 15, 2010. 
provision in the original merger agreement would be enforced. Once the new, topping deal was announced, the plaintiff in the litigation thereupon concluded that the litigation had fully served its function, and moved for a dismissal of the case (and an award of attorney's fees). That motion was granted, and the case ended, without further proceedings and attendant costs. The court's ruling granting expedited discovery contributed to the prompt, effective, and efficient resolution of the litigation.

Where it is denied, a motion to expedite discovery can also promote the efficient resolution of litigation, much as if it were the grant of a motion to dismiss. Stourbridge Investments $L L C v$. Bersoff, et al. ${ }^{207}$ is a remarkable example of this, remarkable because the defendants did not even oppose expedition. ${ }^{208}$ In this litigation “challenging an arm’s length, third party merger agreement,” entered into “after an extensive market canvass,"209 the court responded to plaintiff's motion for expedited discovery by noting that it "conducts a truncated determination of the merits" and inquires whether the merits "are sufficient to impose on both the parties and also on the public and the Court, the increased burden an expedited proceeding entails.” ${ }^{210}$ Noting that the plaintiff's claim must be "sufficiently colorable,” and that "not just any claim will do,” the court ruminated that the liberal attitude toward expedition that Chancellor Allen described in 1994 seemed "quaint,” in light of the "dramatic transformation” in the volume

${ }^{207}$ C. A. No. 7300-VCL (Del. Ch. Mar. 13, 2012) (transcript ruling).

208 This was apparently due to a desire to foster activity in the Delaware litigation in an effort to preserve the Court of Chancery as the primary forum, in preference to a parallel case pending in federal court in Virginia. Id. at 5 (according to defendants' counsel, "We weren't confident we could successfully oppose expedition in both jurisdictions, so we agreed to not oppose in Delaware and have moved to stay in Virginia based upon the pendency of the Delaware case.”). 209 Id. at 7.

${ }^{210} I d$. at 9. 
of public company merger litigation described at the outset of this article. ${ }^{211}$ Expressing the view that the sheer numbers of deal cases indicate "that there are market imbalances here and externalities that are being exploited," 212 the court pointedly denied expedition, describing the case as "really a harvesting case and not a litigating case," and avowing that "I am not going to facilitate leverage to create a harvest settlement in a case like this where there's been absolutely no colorable reason for anyone to be concerned about this deal.”213

Having received the court's preliminary (and harsh) assessment of the merits, plaintiff voluntarily dismissed its complaint on April 17, 2012, just about a month after the court denied its motion to expedite discovery. According to the docket in the matter, no formal discovery requests were ever filed.

\section{E. Limits of Pleading Stage Evaluation of Shareholder Litigation}

Despite our enthusiasm for the Delaware system of pleading stage evaluation of shareholder litigation, we recognize and review in this section several categories of cases in which such evaluation is, for various reasons, impractical or unavailable. As explained below, perhaps none of these categories involves costs that could be efficiently eliminated through improvements in the pleading stage triage system we describe. It is important, however, to recognize the limitations of that system.

${ }^{211}$ Id. at $10-11$.

${ }^{212}$ Id. at 12.

${ }^{213} I d$. at 14 . The court also referred to "the profound weakness of this complaint." Id. at 16. 
Closely held companies. Shareholder litigation of course exists in closely held companies as well as in publicly traded companies. ${ }^{214}$ But in the case of the closely held corporation the need for pleading stage evaluation of shareholder litigation is far less compelling than in the case of the publicly held company. Because the typical minority shareholder in the closely held corporation indirectly bears a more significant share of the corporation's litigation costs than is the case for a typical shareholder plaintiff in a public company, there is less concern that plaintiffs in closely held companies will exploit a disproportionate burden of litigation expense in order to extract settlements in private company litigation. Moreover, shareholder litigation in the closely held corporation is not amenable to class action treatment because similarly situated shareholders are few in number, ${ }^{215}$ and the plaintiffs' bar is unlikely to take on such cases where the financial stakes are typically smaller than in public company litigation and fee awards are therefore also likely to be smaller. In short, there is no significant "merger tax" problem in closely held company shareholder litigation, and policing such litigation by means of pleading stage evaluation of the sort we describe is largely unnecessary. ${ }^{216}$

Statutory appraisal. In recent years, statutory appraisal proceedings have become an increasingly common form of litigation that, like the class action deal litigation we examine,

\footnotetext{
${ }^{214}$ E.g., Zutrau v. Jansing, C.A. No. 7457-VCP (July 31, 2014); C.A. No. 6001-VCP (Jan. 31, 2013); Gould v. Gould, C.A. No. 3332-VCP (Aug. 14, 2012); Dweck, et al. v. Nasser, et al., C.A. No. 1353-VCL (Jan. 18, 2012).

${ }^{215}$ See Court of Chancery Rule 23(a) (providing in pertinent part that a class action may be maintained "only if ... the class is so numerous that joinder of all members is impracticable"). ${ }^{216}$ This is not to say that such early evaluation, based on a robust factual record, is necessarily inappropriate in shareholder litigation involving a closely held company. It may be, in fact, that a minority shareholder in a closely held corporation, especially an employee-shareholder, is better situated than her public company counterpart to provide specific factual allegations to support claims of breach of fiduciary duty.
} 
challenges the terms of mergers. ${ }^{217}$ Like class action deal litigation, appraisal litigation has generated detractors, who focus on perceived abuse by those who purchase shares after a deal is announced, in an effort to profit through receipt of "fair value" in the appraisal litigation that exceeds the deal price. ${ }^{218}$ Others defend appraisal litigation on the grounds that, unlike class actions, it is an opt-in affair, in which participating shareholders' incentives incline them to target deals that are underpriced, thereby minimizing or avoiding the "merger tax" problem of unmeritorious litigation. ${ }^{219}$ We do not take a position here on that debate; what we note, however, is that the motion to dismiss and the motion to expedite discovery - the key procedural vehicles for early stage triage in shareholder class and derivative actions - are essentially foreign to statutory appraisal litigation, because the petitioners in such litigation (a) need not plead any breach of fiduciary duty, ${ }^{220}$ and (b) do not typically seek expedited discovery because appraisal aims at a post-deal cash award, rather than any injunction preventing the deal from going

${ }^{217}$ Korsmo \& Myers, note [ ] above, at [ ] (“Appraisal activity involving public companies is undergoing explosive growth in Delaware, driven by sophisticated parties who specialize in bringing appraisal claims.").

${ }^{218}$ Liz Hoffman, Wall Street Law Firms Challenge Hedge-Fund Deal Tactic, Wall Street Journal (April 6, 2015), available at http://www.wsj.com/articles/wall-street-law-firms-challenge-hedgefund-deal-tactic-1428362171 (reporting major New York law firm advocacy of statutory change that would “"'reduce the unseemly claims-buying that is rampant and serves no legitimate equitable or other purpose").

${ }^{219}$ Korsmo \& Myers, note [ ] above, at [ ] ("the choice to initiate appraisal proceedings appears strongly focused on litigation merit.”).

${ }^{220}$ Ala. By-Products Corp. v. Neal, 588 A.2d 255, 257 (Del. 1991) (“claims for unfair dealing cannot be litigated in the context of a statutory appraisal.”); Turner v. Bernstein, 776 A.2d 530, 545 n.37 (Del. Ch. 2000) (“a statutory appraisal action is different from an equitable action in several respects. In an appraisal, the defendant is the resulting or surviving corporation and is bound to pay the fair value of the petitioners' shares as determined by the court. 8 Del. $C$. § 262(i). In an equitable action, the defendants are the persons (typically the directors) who are alleged to have breached fiduciary duties owed to the plaintiffs, and the plaintiffs must prove a breach to obtain relief.”). 
forward. As a result, the pleading stage evaluation system we describe is irrelevant in appraisal litigation.

Entire fairness cases. We previously noted ${ }^{221}$ that the Delaware courts have now afforded controlling shareholders a road map of procedures that would restore the application of the deferential business judgment rule even to a freeze-out merger. It is unclear, however, whether and to what extent controlling shareholders will choose to travel that road; and controller freeze-out mergers that do not employ the procedures invited by the Delaware courts will continue to be subject to scrutiny for entire fairness. ${ }^{222}$ That strict standard of judicial scrutiny will also apply to other transactions in which a director, officer or controlling shareholder obtains a benefit at the expense of the corporation or its other shareholders. ${ }^{223}$ In such cases, it seems unlikely, or even unthinkable, that a challenge to such a transaction would be dismissed at the pleading stage; even where an ostensibly independent committee of directors approves the transaction, uncertainty about the independence of the directors ordinarily will prevent dismissal at the pleading stage. ${ }^{224}$ But we do not urge that the pleading stage triage

${ }^{221}$ Part III.B.5.iii above.

${ }^{222}$ E.g., Leal v. Meeks, note [] above, [] A.3d at [ ] ("the companies did not follow the process established in Kahn v. M\&F Worldwide Corporation as a safe harbor to invoke the business judgment rule in the context of a self-interested transaction. Thus, the entire fairness standard presumptively applied”).

${ }^{223}$ E.g., Paramount Commc'ns Inc. v. QVC Network Inc., 637 A.2d 34, 42 n.9 (Del. 1994) ("Where actual self-interest is present and affects a majority of the directors approving a transaction, a court will apply . . . exacting scrutiny to determine whether the transaction is entirely fair to the stockholders."); In re Nine Sys. Corp. S'holders Litig., 2014 Del. Ch. LEXIS 171, *99 (Del. Ch. Sept. 4, 2014) ("Absent certain procedural protections not implicated here [namely, the process outlined in Kahn v. M\&F Worldwide], a minority stockholder's challenge to a transaction in which a controlling stockholder stands on both sides implicates the entire fairness standard of review.”).

${ }^{224}$ See, e.g., id. at [ ] (when the entire fairness standard "is invoked at the pleading stage, the plaintiffs will be able to survive a motion to dismiss by interested parties regardless of the presence of an exculpatory charter provision because their conflicts of interest support a 
system needs to expand to reach such cases; these cases are the likely to have substantial merit, and are thus unlikely to present the merger tax problem of extracting settlements or imposing other costs in litigation lacking merit.

\section{CONCLUSION}

In recent years, merger and acquisition activity has generated nearly ubiquitous litigation that to some considerable extent lacks substantive merit. Nevertheless, the risk/reward dynamics of such litigation encourage the defendants to agree to quick settlements with substantial attorneys' fee awards but no payment to shareholders, whether there is a good case, a bad case, or no case at all. Some have suggested that fee-shifting charter and bylaw provisions are an appropriate response to this “merger tax" phenomenon. But while such provisions would certainly discourage the plaintiff's lawyer from bringing a bad case, they would also discourage the plaintiff's lawyer from bringing even a very good case as well.

Active judicial supervision of public company shareholder litigation, at an early stage, provides a better solution that reduces the costs of frivolous litigation to shareholders, while maintaining the incentive for the plaintiffs' bar to search for cases where directors have breached a fiduciary duty owed to shareholders. Using procedures and doctrines that have not previously been catalogued and appreciated as a coherent set of interrelated dynamics, the Delaware Court of Chancery provides a model for such a solution: it is a specialized court whose docket is

pleading-stage inference of disloyalty.”); Krasner v. Moffett, 826 A.2d 277, 286 (Del. 2003) ("The independence of the special committee involves a fact-intensive inquiry that varies from case to case. Thus, we cannot assume at the pleading stage that the defendants will carry the burden of establishing independence. Beyond that, it is premature to determine the legal effect-and the resulting standard of review--that would apply if a special committee that operated independently recommended a merger to the full board.”). 
primarily business transaction cases, and whose judges become experts at evaluating a complaint and defendants' responses and deciding quickly whether the case has substantive merit.

We show above that in the hands of the Court of Chancery, the motion to dismiss has become the primary procedural vehicle for accomplishing that early stage triage of shareholder litigation. We demonstrate that the Court of Chancery employs the motion to dismiss to engage in a factually robust analysis of the merits, despite liberal pleading standards that ostensibly preclude dismissal where the pleaded facts make a viable claim appear "reasonably conceivable” or “colorable.” We demonstrate that such early stage analysis depends upon a judicial insistence on pleading, or allowing for dismissal stage consideration of, essentially undisputed facts, and upon the availability of such facts to the plaintiff shareholder through sources that compensate for the problem of asymmetric access to relevant information. We thus suggest that the motion to dismiss in representative shareholder litigation has thus come to resemble, and substitute for, the motion for summary judgment. The Delaware courts’ atypical demand for, and unusual willingness to consider, extensive facts in resolving motions to dismiss encourage defendants to supply relevant information voluntarily, on a cost efficient basis that avoids largely unlimited discovery. Finally, our assessment of the pleading stage triage system suggests that where time constraints, most notably in deal litigation, preclude disposition via a motion to dismiss, the motion for expedited discovery must necessarily come to serve the same efficiency promoting functions as the motion to dismiss, And indeed, we observe that in resolving motions to expedite discovery in deal litigation, the Court of Chancery has come to apply essentially the same level of substantive factual review of the merits encountered in resolving motions to dismiss.

The result is a system in which cases settle at the motion to dismiss stage and few make it to trial on the merits. In the period 2011 to 2014, only four public company class and derivative 
cases were decided after trial. The Delaware system thus has already achieved a high degree of efficiency in resolving such litigation. There are areas - closely held company shareholder litigation, statutory appraisal litigation, and entire fairness cases - in which the efficiency of early stage resolution is not or cannot be achieved, and perhaps appropriately so. But with the likely concentration of deal litigation in the Delaware courts resulting from increasingly prevalent exclusive forum charter and bylaw provisions, the motion to dismiss and the motion to expedite discovery are likely to become even more important in promoting the efficient conduct of shareholder class and derivative litigation involving public companies.

Even in the class and derivative litigation in which the merger tax problem arises, however, Delaware’s pleading stage triage system does not entirely eliminate that problem. Briefing and arguing a motion to dismiss is not cost-free, and rational defendants could conclude that they are better off settling early on based on supplemental disclosures and paying a plaintiff's attorney fee, rather than pursue even a viable motion to dismiss. And despite increased interest in judicial scrutiny of such settlements, ${ }^{225}$ and increasing use of exclusive forum selection bylaws that will alleviate the tendency of multi-forum litigation to encourage such "merger tax" settlements, ${ }^{226}$ some level of "merger tax" is unavoidable, as long as class and derivative litigation is to remain a viable tool to enforce fiduciary duties. But no system is perfect, and agency costs in representative shareholder litigation, as in any setting, cannot be expected to be reduced to zero.

${ }^{225}$ See text at note [ ] above.

${ }^{226}$ Lawrence A. Hamermesh, How Long Do We Have to Play the “Great Game?,” 100 IowA L. REV. BuLL. 31, [ ] (2015); Explanatory Memorandum, note [ ] above, at 9 ("To the extent the prevalence of multi-forum litigation has made the Delaware courts reluctant to police stockholder litigation, [the proposed legislation's] enhanced means to end the multi-forum litigation problem should increase judicial confidence to use the tools available to supervise stockholder litigation more effectively”). 
Working Paper - draft of 8-19-15 